\title{
Assessment of mechanical properties of fibrous mortar and interlocking soil stabilised block (ISSB) for low-cost masonry housing
}

\author{
F. Qamar ${ }^{\mathrm{a}} \bowtie$, T. Thomas ${ }^{\mathrm{b}}, \mathrm{M} . \mathrm{Ali}^{\mathrm{c}}$ \\ a. University of Warwick (Warwick, UK) \\ b. Engineering Dept. University of Warwick (Warwick, UK) \\ c. Department of Civil Engineering, Capital University of Science and Technology (Islamabad, Pakistan)
} $\bowtie$ f.qamar@warwick.ac.uk

\author{
Received 15 December 2018 \\ Accepted 21 May 2019 \\ Available on line 25 September 2019
}

\begin{abstract}
Walls of Interlocking Stabilised Soil Blocks (ISSBs) have been considered in low-cost houses around the world especially in developing countries. These were reported to be very weak in resisting the lateral load (e.g. wind or earthquake) without special considerations. In this paper, mechanical properties (compressive strength, elastic modulus, pre/post crack energy absorbed and toughness index) of ISSBs with three configurations and seven combinations of plain and fibrous mortar cubes are experimentally evaluated. Sisal fibre and rice straw ( $2 \%$ and $5 \%$, by cement mass) were considered for fibrous mortar. Empirical equations were developed to predict elastic modulus. It was found that ISSBs had reasonable strength to be considered for masonry. The failure load and toughness index of $2 \%$ sisal fibre samples was improved by $10 \%$ and $16 \%$, respectively, whereas 2.21 times enhancement was found in elastic modulus. Thus, $2 \%$ sisal fibre in plaster (i.e. reinforced coating) would likely improve the lateral resistance of interlocked masonry walling.
\end{abstract}

KEYWORDS: Brick; Mortar; Mechanical properties; Fibre reinforcement; Image analysis.

Citation/Citar como: Qamar, F.; Thomas, T.; Ali, M. (2019) Assessment of mechanical propertiesof fibrous mortar and interlocking soil stabilised block (ISSB) for low-cost masonry housing. Mater. Construcc. 69 [336], e201 https://doi. org $/ 10.3989 / \mathrm{mc} .2019 .13418$

RESUMEN: Evaluación de las propiedades mecánicas de morteros fibrosos y bloques de suelo estabilizado y entrecruzado (ISSB) para viviendas de mampostería de bajo costo. Los muros de bloques de suelo estabilizados entrelazados (ISSB) se han utilizado en casas de bajo costo en todo el mundo, especialmente en países en desarrollo. Es conocido que estos muros presentaban debilidad frente a cargas laterales (por ejemplo, viento o terremoto) sin consideraciones especiales. En este trabajo se han evaluado las propiedades mecánicas (resistencia a compresión, módulo elástico, absorción de energía pre/post agrietamiento e índice de tenacidad) de ISSB con tres configuraciones y siete combinaciones de cubos de morteros liso y fibrosos. Para los morteros fibrosos se utilizó fibra de sisal y paja de arroz en proporciones del $2 \%$ y $5 \%$ con respecto a la masa de cemento. Se desarrollaron ecuaciones empíricas para predecir el módulo elástico. Los resultados mostraron que los ISSB poseen una fortaleza suficiente para poder ser utilizados en obras de albañilería. La carga de falla y el índice de tenacidad de las muestras de fibra de sisal al $2 \%$ se mejoraron en un $10 \%$ y un $16 \%$, respectivamente, mientras que se encontró una mejora de 2.21 veces en el módulo de elasticidad. Por lo tanto, un $2 \%$ de fibra de sisal en yeso (es decir, revestimiento reforzado) probablemente mejoraría la resistencia lateral de las paredes.

PALABRAS CLAVE: Ladrillo; Mortero; Propiedades mecánicas; Refuerzo de fibras; Análisis de imágenes.

ORCID ID: F. Qamar (https://orcid.org/0000-0003-2240-1035); T. Thomas (https://orcid.org/0000-0001-9903-067X); M. Ali (https://orcid.org/0000-0002-3690-2183)

Abbreviations: ISSBs, Interlocked soil stabilized blocks; PE , Pre-crack absorbed energy for mortar cubes $\left(\mathrm{MJ} / \mathrm{m}^{3}\right)$; $\mathrm{CE}_{\mathrm{p}}$, Post-crack absorbed energy for mortar cubes $\left(\mathrm{MJ} / \mathrm{m}^{3}\right) ; \mathrm{TE}_{\mathrm{p}}$ Total absorbed energy for mortar cubes $\left(\mathrm{MJ} / \mathrm{m}^{3}\right)$; $\mathrm{CTI}_{\mathrm{p}}$, compressive toughness index of mortar cubes (-); $\mathrm{C}_{\mathrm{p}}$, compressive strength of mortar cubes (MPa); $\mathrm{E}_{\mathrm{p}, \text { Modulus }}$ of elasticity of mortar cubes $(\mathrm{GPa}) ; \mathrm{PE}_{\mathrm{b}}$, pre-crack absorbed energy for block $\left(\mathrm{MJ} / \mathrm{m}^{3}\right) ; \mathrm{CE}_{\mathrm{b}}$, post-crack energy absorbed for block $\left(\mathrm{MJ} / \mathrm{m}^{3}\right) ; \mathrm{TE}_{\mathrm{b}}$ total energy absorbed for block $\left(\mathrm{MJ} / \mathrm{m}^{3}\right) ; \mathrm{CTI}_{\mathrm{b}}$ compressive toughness index for block (-); $\mathrm{C}_{\mathrm{b}}$ compressive strength of block (MPa); $\mathrm{E}_{\mathrm{b}}$, modulus of elasticity of block (GPa); kN, kilo-Newton; mm, millimeter; MPa, mega Pascal; GPa, giga Pascal;J/m3, Joule per cubic metre.

Copyright: (C) 2019 CSIC. This is an open-access article distributed under the terms of the Creative Commons Attribution 4.0 International (CC BY 4.0) License. 


\section{INTRODUCTION}

Due to increase of population in developing countries the need forlow-cost residential housing has increased considerably around the world $(1,2)$. At the same time need for a faster construction system has led to the change in conventional approach of masonry construction to interlocking construction technique. Interlocking masonry units or blocks can be laid without layers of mortar and require less labour (3-5). Interlocking masonry units differ from conventional blocks in that these units can be assembled with geometrical features built into blocks without the need of a mortar layer (6). Most interlocking blocks available in the industry differ in geometry, material and dimensional features. As wellas advantages of removal of bedding mortar and reduction in cost, interlocking blocks have some limitations. These include the requirement of strict dimensional tolerance and reduced lateral resistance. The structural behaviour of an interlocking block wall of a masonry house may differ from that of a conventional masonry wall when subjected to in-plane and out-of-plane loading due to geometrical imperfection (7-10). Masonry walls are mostly used in resisting compressive and horizontal (out-of-plane) loading like wind and earthquake. Therefore, the structural performance of the interlocking wall under these loadings is a primary concern $(11,12)$. In previous studies different types of interlocking block, mainly depending on material, geometry and interlocking mechanism, were used. Different types of mechanical property were explored, as detailed in Table 1. In research undertaken by Fundi et al. 2018 cement-stabilised soil blocks were used to test the behaviour of small wall (900 mm length and $1200 \mathrm{~mm}$ height) for vertical and horizontal loading. The optimisation of compressive strength of blocks by the addition of cement stabiliser was also determined and a minimum of 2.5 MPa compressive strength found which could be increased to $4.5 \mathrm{MPa}$ at 28 days' curing by the addition of lime in soil and cement. In another study by Anand (6)the compressive strength of interlocking concrete blocks was reported to be $5.42 \mathrm{MPa}$ for single block (400 $\mathrm{mm} \times 150 \mathrm{~mm} \times 100 \mathrm{~mm})$ and 3.77 MPa for small wall (400 mm x $600 \mathrm{~mm}$ x $100 \mathrm{~mm}$ ). Shear and tensile strengths were also reported to be $0.48 \mathrm{MPa}$ and $0.21 \mathrm{MPa}$ respectively. In a study by Lee (1), where interlocking block columns were built and interlocking holes were infilled with mortar and the reinforcement, the material properties and failure behaviour were studied and the compressive strength of $14.28 \mathrm{MPa}$ was reported for interlocking blocks. In research conducted by Jaafar (3) hollow interlocking blocks were used and a correlation developed between the compressive strength of a single block, prism and wall panel. It was found that the compressive strength of a single block was 15.2 MPa. The prism and wall panel compressive strengths were 0.47 and 0.39 respectively, times the strength of interlocking block. In all research studies the compressive strength of different types of interlocking block was measured and found to be in the range of 2.5-16.48 $\mathrm{MPa}$. Other mechanical properties like shear strength and compressive toughness were also measured and found to be in the range of $0.48-2.65 \mathrm{MPa}$ and 0.56 , respectively. It became evident from the outcome of different studies that properties of interlocking block vary depending on geometry, material and interlocking mechanism and could affect the overall strength of masonry wall.

As reported in the literature, interlocking block wall showed reduced lateral resistance to wind and earthquake. Therefore, to enhance lateral resistance, different techniques, like plain or reinforced grouting, surface bonding and plastering, were used (6). Use of natural fibres in mortar was considered in a variety of studies and the mechanical properties of specimens with and without fibres were compared, as detailed in Table 2. In a study by Pereira (13) mechanical properties like compressive and bending strength and toughness of plain mortar and mortar with sisal fibres were compared. It was observed that there was a $21 \%$ decrease in compressive strength with the addition of fibres, but a $60 \%$ and $600 \%$ increase in bending strength and toughness respectively were reported. In research

TABLE 1. Mechanical properties of ISSBs by other researchers

\begin{tabular}{lcccccc}
\hline & $\begin{array}{c}\text { Compressive } \\
\text { Strength } \\
\text { Type of block }\end{array}$ & $\begin{array}{c}\text { Modulus of } \\
\text { Elasticity } \\
\text { (GPa) }\end{array}$ & $\begin{array}{c}\text { Shear } \\
\text { Strength } \\
\text { (MPa) }\end{array}$ & $\begin{array}{c}\text { Compressive } \\
\text { Toughness } \\
\text { (MPa) }\end{array}$ & $\begin{array}{c}\text { Shear } \\
\text { Toughness } \\
\text { (MPa) }\end{array}$ & References \\
\hline $\begin{array}{l}\text { Coconut fibre reinforced } \\
\text { concrete interlocking block }\end{array}$ & 16.48 & 2.34 & 2.65 & 0.56 & 7.59 & Ali et al. 2012 \\
$\begin{array}{l}\text { Solid interlocked block } \\
\text { Hollow Interlock block }\end{array}$ & 5.42 & - & 0.48 & - & - & Anand et al. 2000 \\
$\begin{array}{l}\text { Interlocking block } \\
\begin{array}{l}\text { Cement stabilised soil } \\
\text { interlocking block }\end{array}\end{array}$ & 15.2 & - & - & - & - & Jaafar et al. 2006 \\
\hline
\end{tabular}


TABLE 2. Mechanical properties of fibre reinforced mortar by other researchers

\begin{tabular}{lcccccl}
\hline Type of Fibre & $\begin{array}{c}\text { Fibre Volume } \\
\text { Fraction } \\
\text { (\%age) }\end{array}$ & $\begin{array}{c}\text { Compressive } \\
\text { Strength } \\
\text { (MPa) }\end{array}$ & $\begin{array}{c}\text { Modulus of } \\
\text { Rupture /Flexural } \\
\text { Strength* } \\
\text { (MPa) }\end{array}$ & $\begin{array}{c}\text { Toughness } \\
\text { Index }\end{array}$ & $\begin{array}{c}\text { Modulus of } \\
\text { Elasticity } \\
\text { (GPa) }\end{array}$ & References \\
\hline Plain & 0 & 28 & $5^{*}$ & 0.45 & - & Pereira et al. (2015) \\
Sisal & $3 \%$ & 22 & $8^{*}$ & 3.28 & - & Pereira et al. (2015) \\
Sisal & $8 \%$ & - & 16.8 & 1.41 & 6.07 & Savastano et al. (2009) \\
Banana & $8 \%$ & - & 21.8 & 0.59 & 6.7 & Savastano et al. (2009) \\
Basalt & $4 \%$ & 29 & $8.9^{*}$ & - & - & Teresa et al. (2012) \\
Coconut & $5 \%$ & 41 & $10^{*}$ & - & - & Lertwattanaruk et al. (2015) \\
Oil palm & $5 \%$ & 36 & $8^{*}$ & - & - & Lertwattanaruk et al. (2015) \\
Polypropylene & $0.5 \%$ & 21 & $7.50^{*}$ & - & 7.9 & Islam et al. (2011) \\
\hline
\end{tabular}

by Savastano $(14,15)$ natural fibres like sisal and banana with cementitious composite were tested under three-point bending. Mechanical properties, including flexural strength, modulus of elasticity and toughness index were obtained and compared with those of non-fibrous composite. It was found that the addition of fibres resulted in $100 \%$ improvement in flexural strength and significant enhancement of toughness index. This could be of interest where cement-based components are exposed to lateral loading like wind and earthquake. Basalt-fibre reinforced mortar was tested by Zych (16) and Asadi (17). A $20 \%$ increase in bending strength and $15 \%$ reduction in compressive strength were found to be due to the addition of fibres. This finding/ result isconsistentwith that of Pereira (13). In a study by Ali (18) coconut-fibre reinforced concrete cylinders and beamlets were tested for dynamic and mechanical properties and it was found that fibre content of $5 \%$ gave best properties. Lertwattanaruk (19) used coconut and oil palm fibre in cementitious composite which was tested for mechanical properties prior to its recommendation for residential housing application. Differing fibre content of $5 \%, 10 \%$ and $15 \%$ by mass of cement was used and it was found that increasing the fibre content resulted in lower compressive and flexural strengths. In a study by Toihidul Islam(20) impact resistance of masonry units bounded with fibrous mortar was investigated. Mechanical properties including compressive and flexural strength were also evaluated for fibrous cementitious composites. It was found that $0.5 \%$ fibre content in the mortar improved impact resistance of masonry unit, whereas bond strength was reduced with an increase in fibre content from $0-0.5 \%$. The outcome of these various studies has indicated that type and content of fibre influences the mechanical properties of cementitious material.

In otherstudies, the performance of interlocking block masonry wall was tested and it was found that the compressive properties of the wall were directly related to the strength of masonry units (8).
Therefore, in this study material properties of interlocking soil-stabilised block (ISSB) are explored for their possible use in a typical masonry house, as shown in the Figure 1.

Figure 1 shows the plan, elevation and section of a proposed masonry house. Walls consist of single ISSB width having block projecting outside wallat regular intervals for its stability. A timber roof truss is anchored to walls with steel ties. The structure is mortar-free and lateral resistance is to be ensured by interlocking mechanism and plastering. The mechanical properties of ISSB and fibrous mortar reported by other researchers are detailed in Tables 1 and 2. It was found that for ISSB only compressive strength had been measured: other properties like modulus of elasticity, pre/post crack energy absorbed, total energy absorbed and toughness index had not been evaluated. As these latter properties are required for modelling wall performance they need to be measured. To the author's knowledge there is no study where mechanical properties of interlocking blocks had been evaluated relatingto the overall performance of a masonry structure. Therefore it is important to assess the mechanical properties for ISSB. On the other hand, for fibrous cementitious matrix as a plaster (reinforced coating), some evidence of mechanical properties like compressive strength, flexural strength and toughness index is available, but only for natural and artificial fibres possessing high tensile strengths. Therefore, the mechanical properties (as detailed earlier) of sisal, rice straw and treated rice straw cementitious matrix were experimentally evaluated. $2 \%$ and $5 \%$ of fibre content, by mass of cement and $50 \mathrm{~mm}$ in length, were used. Mortar cube samples were tested as per standard BS EN 1015-11(21). Surface morphology of sisal, rice straw and treated rice straw were compared using Bruker 3D optical microscope to evaluate the surface roughness of fibres. Microscopic observation of tested mortar samples was carried out to study the bond between the fibres and mortar. Empirical 


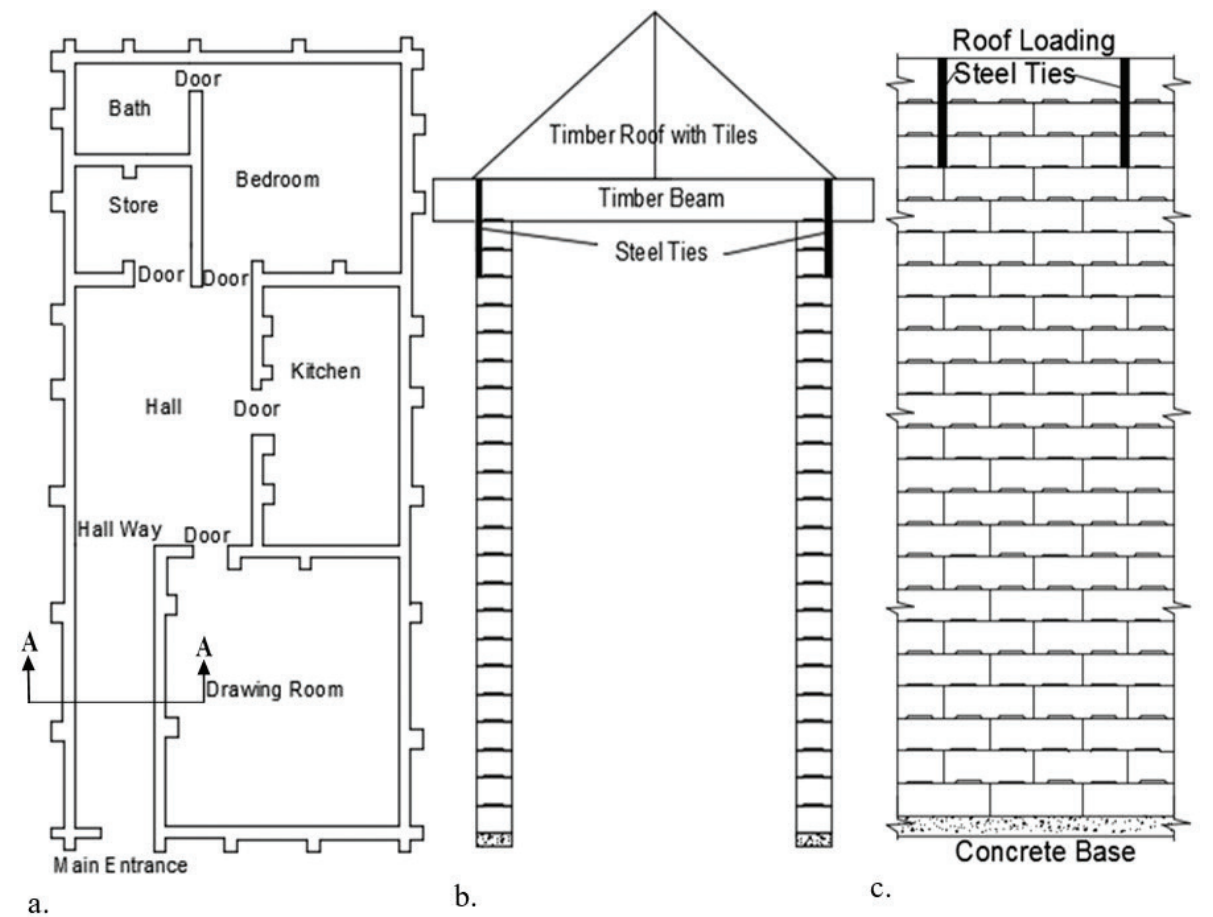

FIgURE 1. Schematic diagram of proposed technique for house construction a. Plan, b. Section and c. Elevation.

relations were also developed between compressive strength and modulus of elasticity with the help of experimental data, for the interlocking block, plain and fibrous mortar.

\section{EXPERIMENTAL PROCEDURE}

\subsection{Materials and composition}

In the preparation of interlocking soil-stabilised blocks soil and ordinary Portland cement were used. Soil was outsourced from Boko quarries Dar es Salam and it was obtained at a depth of $1 \mathrm{~m}$ below the earth surface in order to eliminate the addition of humus materials. The cement was sourced from Twiga cement factory Dar es Salam. Chemical and physical properties as adopted from the manufacturer are shown in Table 3. Similar chemical composition of portland cement was reported by Jaurez (4) and Zych (16). The physical properties of cement reported in Table 3 were also described by Lertwattanaruk (19). The properties of soil used for ISSB are detailed in Table 4, as reported by (7). In this study it was reported that the addition of fibres resulted in an increase in porosity and water absorption and a decrease in density as compared with non-fibrous samples, which was consistent with findings of other studies by $(22-25)$.

The same cement was used for the preparation of plain and fibrous mortar cubes. Three types/ conditions of natural fibre were used, including
TABLE 3. Chemical and physical properties of cement used

\begin{tabular}{llc}
\hline Properties & Type & Values \\
\hline Chemical properties & $\mathrm{SiO}_{2}$ & $17.55 \%$ \\
& $\mathrm{Al}_{2} \mathrm{O}_{3}$ & $4.70 \%$ \\
& $\mathrm{Fe} 2 \mathrm{O}_{3}$ & $1.77 \%$ \\
& $\mathrm{CaO}$ & $64.74 \%$ \\
& $\mathrm{MgO}$ & $1.26 \%$ \\
& $\mathrm{Na}_{2} \mathrm{O}$ & $0.37 \%$ \\
Physical properties & Porosity & $12.21 \%$ \\
& Density $\left(\mathrm{g} / \mathrm{cm}^{3}\right)$ & 2.11 \\
& Water Absorption & $5.96 \%$ \\
\hline
\end{tabular}

TABLE 4. Properties of soil used for ISSB

\begin{tabular}{lc}
\hline Soil Property & Values (\%) \\
\hline Grain size distribution: & \\
Sand & 70 \\
Clay & 23.3 \\
Silt & 6.7 \\
Shrinkage & $7.5-9.17$ \\
Atterberg limits: & \\
Liquid limit & 31.70 \\
Plastic limit & 22.90 \\
Plasticity index & 8.80
\end{tabular}



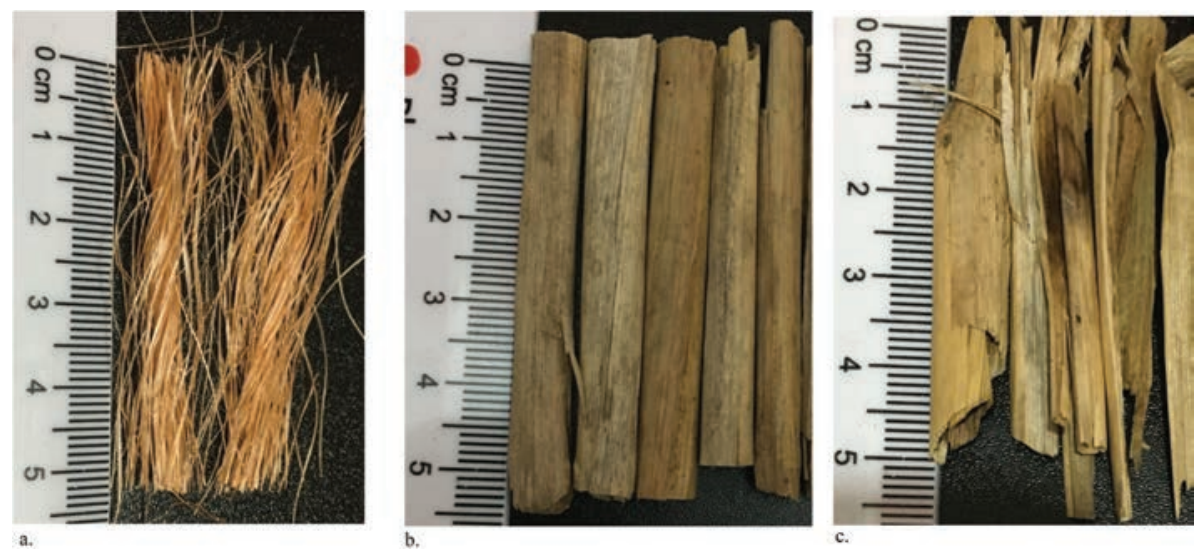

Figure 2. Fibres used, a. Sisal, b. Rice straw, and c. Treated rice straw.

TABle 5. Properties of sand used

\begin{tabular}{lc}
\hline Properties & Value \\
\hline Fineness Modulus & 2.14 \\
Dry Unit Weight $\left(\mathrm{kN} / \mathrm{m}^{3}\right)$ & 14.89 \\
Density $\left(\mathrm{g} / \mathrm{cm}^{3}\right)$ & 2.51 \\
Absorption \% & 1.77 \\
Moisture & 7.08 \\
\hline
\end{tabular}

sisal, rice straw and treated rice straw as shown in Figure 2. Sisal and rice straw are classified as naturalfibres, which are further categorised as plant fibres based on their origin (25). The length of the fibres was about $50 \mathrm{~mm}$. The width of rice straw was about $7 \mathrm{~mm}$ and the diameter of sisal fibres was reported to be $100 \pm 300 \mu \mathrm{mm}(26,27)$. These were obtained locally from Kibaha district Dar es Salam. In the case of treated rice straw fibres were washed using portable water and then boiled for half an hour. The boiled water was then drained and fibres were washed again and then left to dry in the sun before use in mortar cubes. In mortar cube preparation river sand obtained from Kibaha district Dar es Salam was also used. The properties of sand as obtained from supplier are detailed in Table 5. Similar properties of sand were reported by Khonsari (28). Sand of relative density of 2.51 , absorption of $1.77 \%$ and fineness modulus of 2.14 , classified as fine aggregates, was used.

\subsection{Mix ratio and specimen preparation}

\subsubsection{Plain and fibrous mortar cubes}

The mix proportions for plain and fibrous mortar cubes are listed in Table 6. Cement and sand were dry mixed and water was added to make a workable mix. For fibrous mortar cubes fibres were added to a dry mix of cement, sand and water was added later to make it a workable mix. $2 \%$ and $5 \%$ (by mass of cement) fibre contents were used. Mortar mixes for fibrous and non-fibrous samples were cast into cubes of dimensions $100 \mathrm{~mm}$ x 100 $\mathrm{mm} \times 100 \mathrm{~mm}$. In order to ensure uniformity in test conditions the cubes were poured from the same batch of mortar. The specimens were kept in their moulds and demoulded after 7 days. They were stored at ambient temperature and humidity for at least 28 days before testing as per BS EN 1015-11(21).

\subsubsection{ISSBS}

ISSBs were available in the National Housing and Building Research Agency Tanzania (NHBRA) which were prepared using manually pressed machine with dimensions of $300 \mathrm{~mm}$ (length) $\mathrm{x}$ $150 \mathrm{~mm}$ (width) x $100 \mathrm{~mm}$ (height). The soil-cement ratio for ISSBs was 12: 1 .

\subsection{Testing}

The cubes and blocks were tested as per standards $(21,29)$ in a universal testing machine and were instrumented as shown in Figures 3 and 4, respectively, to derive the stress-strain response. The loading surface was kept plane and parallel by the use of steel plates for cubes and a wooden frame for blocks. Generally, three samples of each case were tested to obtain an average. In total 18 samples of mortar cubes with different combinations as detailed in Table 6 were tested. Nine samples of blocks were tested with three arrangements, as shown in the Figure 4. The mechanical properties, which include compressive strength, pre and post crack energy absorbed, total energy absorbed, modulus of elasticity and toughness index were observed. Surface morphology of sisal, rice straw and treated rice straw was compared using Bruker $3 \mathrm{D}$ optical microscope to evaluate the surface 
TABLE 6. Mix proportion and labelling of mortar specimens

\begin{tabular}{lcccc}
\hline & & & & \\
\cline { 3 - 4 } Combinations & Sample Symbol & Cement: Sand & W/C ratio & Fibre content* \\
\hline Plain Mortar Cubes & $\mathrm{A}$ & $1: 3$ & 0.50 & - \\
$2 \%$ Rice Straw Mortar Cubes & $\mathrm{B}$ & $1: 3$ & 0.67 & $2 \%$ \\
2\% Sisal Mortar Cubes & $\mathrm{C}$ & $1: 3$ & 0.67 & $2 \%$ \\
$5 \%$ Rice Straw Mortar Cubes & $\mathrm{D}$ & $1: 3$ & 0.67 & $5 \%$ \\
$5 \%$ Sisal Mortar Cubes & $\mathrm{E}$ & $1: 3$ & 0.67 & $5 \%$ \\
$2 \%$ Treated Rice Straw Mortar Cubes & $\mathrm{F}$ & $1: 3$ & 0.67 & $2 \%$ \\
\hline
\end{tabular}

Note: * by mass of cement

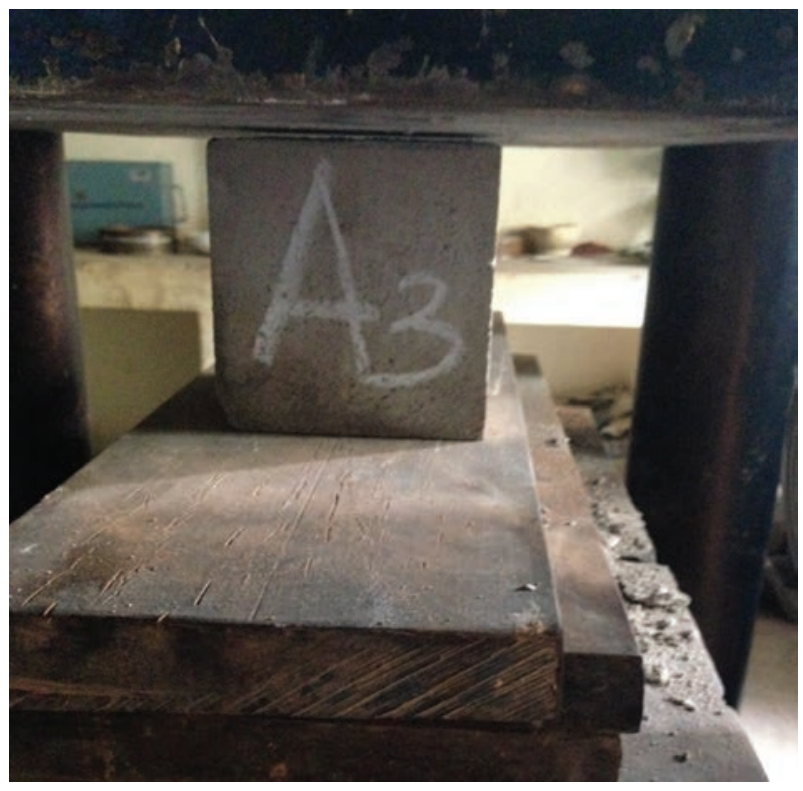

Figure 3. Typical test set up for mortar cubes.

roughness of fibres. Microscopic observation of tested mortar samples was carried out to study the bond between the fibres and mortar. Empirical relations were also developed between compressive strength and modulus of elasticity with the help of experimental data, for the interlocking block, plain and fibrous mortar.

\section{RESULTS AND ANALYSIS}

\subsection{Compressive properties of mortar cubes}

\subsubsection{Compressive behaviour of mortar cubes}

The compressive stress-strain curves are shown in Figure 5 (a-f) for each sample of fibrous and non-fibrous mortar cubes. In all cases samples with fibres showed higher stress and strain as compared with plain mortar sample resulting in enhanced ductility due to the presence of fibre. In Figures $5 \mathrm{c}$ and 5 e, which represent $2 \%$ and $5 \%$ sisal fibres samples, much higher stiffness and ductility are observed than in the case of all other samples. This is due to the high tensile strength of sisal fibre and its presence in the mix bridges the cracks and resists deformation. Figure 6 (a-f) shows the fractured surfaces of tested samples. Figure 6a shows the tested plain mortar sample and crushing failure of the sample is observed leading to the spalling. Figures $6 \mathrm{~b}$ and $6 \mathrm{~d}$ (samples with $2 \%$ and $5 \%$ rice straw) show buldging effect due to the presence of fibre and provide the ability of taking greater load. Figures $6 \mathrm{c}$ and $6 \mathrm{e}$ (samples with $2 \%$ and $5 \%$ sisal fibre) show the bridging effect due to their high tensile strength. This bridging effectalso shows the ability to delay the progression of cracks causing increased failure load. In the case of fibrous samples, the intentionally broken sample revealed that the debonding of fibres was also observed, instead of breaking of fibres as shown in Figure 6d. This greater debonding and reduced fibre fracture may be due to the higher tensile strength of fibres and lower bond strength.

\subsubsection{Compressive strength, compressive pre-crackl post-crack, absorbed energies and compressive toughness index of mortar cubes}

Compressive strength was taken as the peak value of stress from the stress-strain curve. The area below the stress-strain curve up to the stress of first crack was defined as pre-crack absorbed energy $\mathrm{PE}_{\mathrm{p}}$. The area below the stress-strain curve from the first crack stress to maximum load was consideredto be post crack energy absorbed $\mathrm{CE}_{\mathrm{p}}$. The total area below the stress-strain curve from initial to maximum load was categorised as total energy absorbed $\mathrm{TE}_{\mathrm{p}}$. Compressive toughness index (CTI)p was determined by the ratio of total energy absorbed (TEp) and pre-crack energy absorbed PEp. Table 7 shows the average values of first crack load, maximum load, compressive strength, PEp, CEp, TEp and CTIp of samples A to F. It can be observed $17 \%$ and $5 \%$ improvement in the first crack load by addition of 

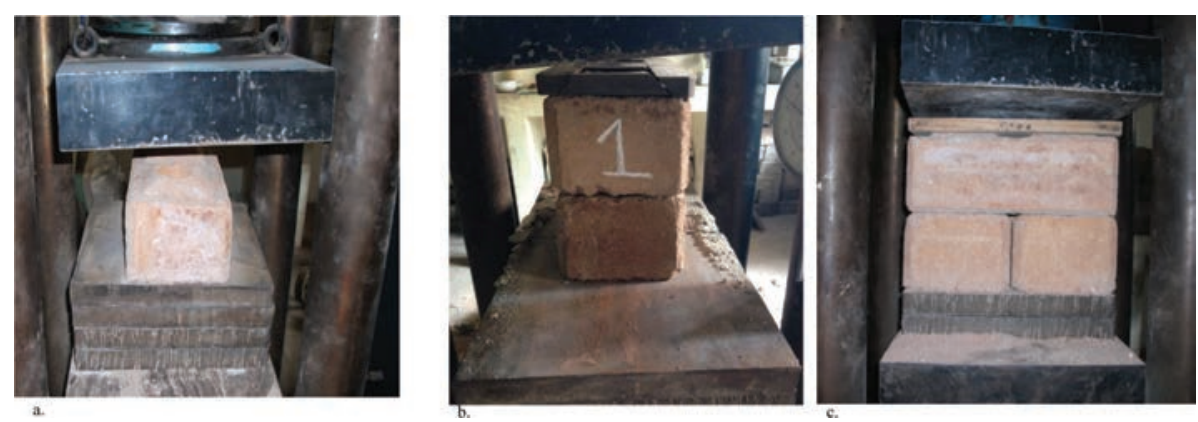

Figure 4. Test set up of ISSBs, a. Single block, b. 1x2 blocks, and c. $2 \times 2$ blocks.
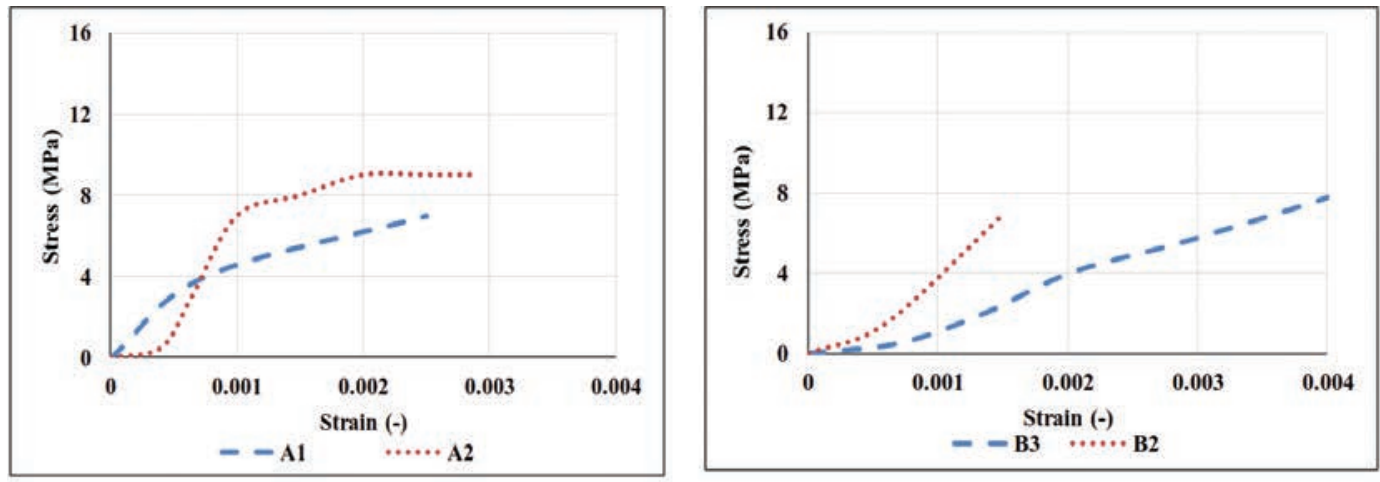

a.

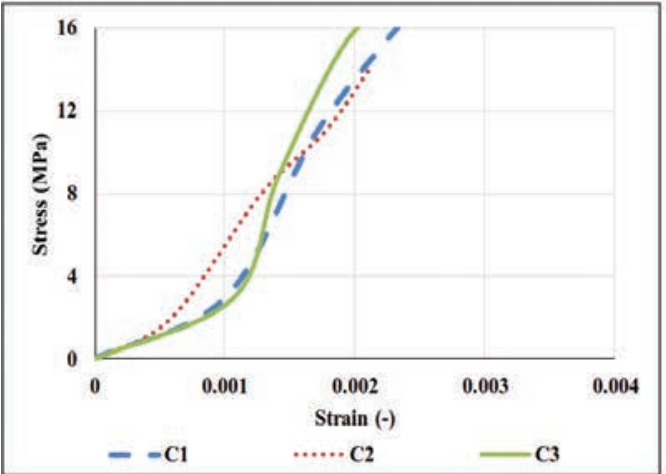

c.

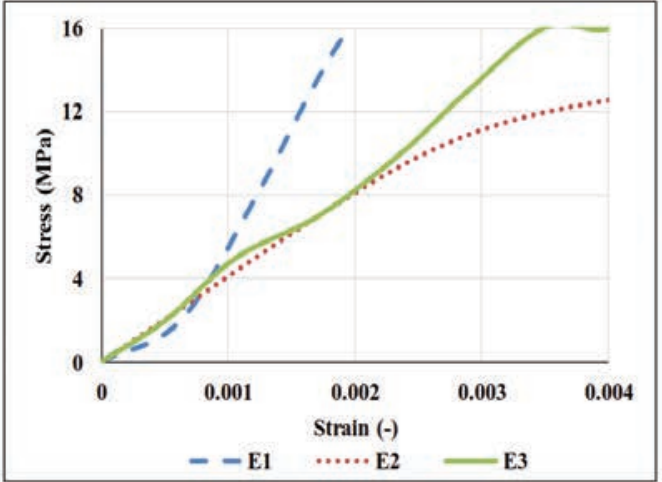

e.

b.

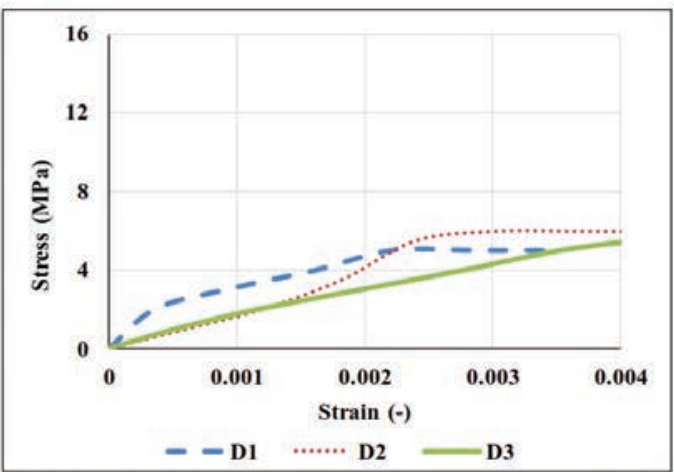

d.

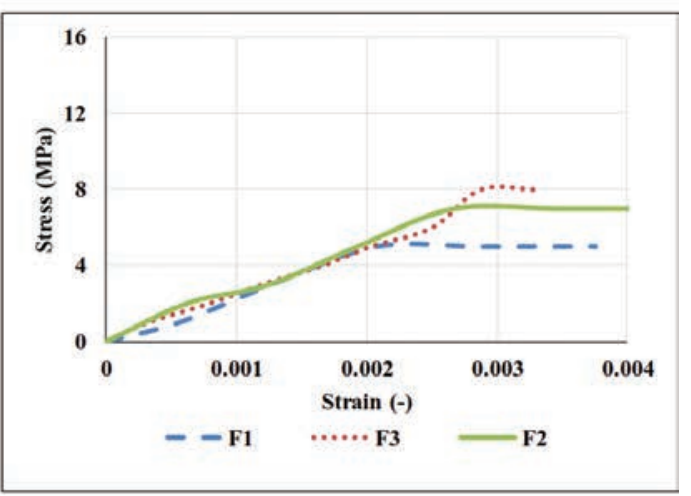

f.

FiguRE 5. Stress strain curves for a. Plain mortar, b. 2\% Rice straw reinforced mortar, c. 2\% Sisal fibre reinforced mortar, d. 5\% Rice straw reinforced mortar, e. 5\% Sisal fibre reinforced mortar, and f. 2\% Treated rice straw reinforced mortar. 

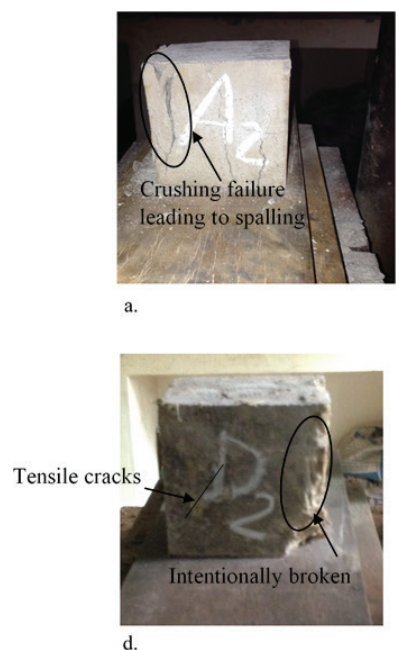
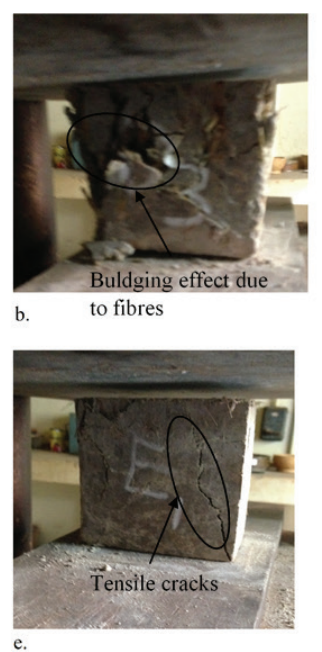
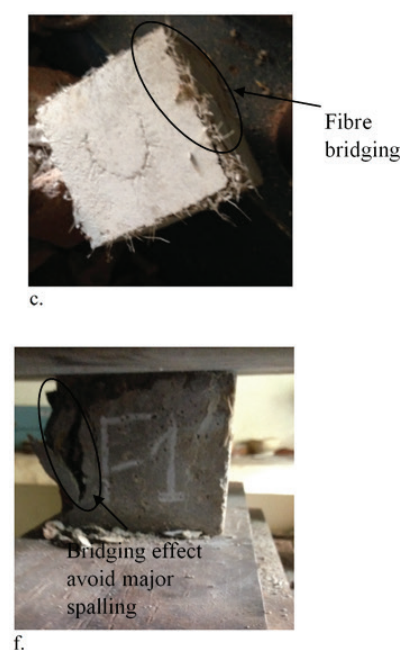

FIGURE 6. Fractured surfaces, a. Plain mortar, b. 2\% Rice straw reinforced mortar, c. 2\% Sisal fibre reinforced mortar, d. 5\% Rice straw reinforced mortar, e. $5 \%$ Sisal fibre reinforced mortar, and f. $2 \%$ Treated rice straw reinforced mortar.

TABLE 7. Compressive properties of fibre reinforced mortar

\begin{tabular}{|c|c|c|c|c|c|c|c|c|c|}
\hline Specimen & $\begin{array}{c}\text { First crack } \\
\text { load } \\
(k N)\end{array}$ & $\begin{array}{c}\text { Max load } \\
(\mathbf{k N})\end{array}$ & $\begin{array}{c}\text { Compressive } \\
\text { Strength Cp } \\
\text { (MPa) }\end{array}$ & $\begin{array}{l}\text { Failure } \\
\text { Mode }\end{array}$ & $\begin{array}{c}\text { Pre-crack } \\
\text { energy } \\
\text { absorbed } \\
\mathbf{P E}_{\mathrm{p}} \\
\left(\mathbf{M J} / \mathbf{m}^{3}\right)\end{array}$ & $\begin{array}{c}\text { Post-crack } \\
\text { energy } \\
\text { absorbed CE } \\
\left(\mathrm{MJ} / \mathrm{m}^{3}\right)\end{array}$ & $\begin{array}{c}\text { Total energy } \\
\text { absorbed } \\
\text { TE }_{\mathbf{p}} \\
\left(\mathbf{M J} / \mathbf{m}^{3}\right)\end{array}$ & $\begin{array}{c}\text { Compressive } \\
\text { toughness } \\
\text { index } \\
\text { CTI }_{p} \\
(-)\end{array}$ & $\begin{array}{l}\text { Modulus of } \\
\text { Elasticity } E_{p} \\
\quad(\mathrm{GPa})\end{array}$ \\
\hline A & $90.5 \pm 44$ & $160.0 \pm 44$ & $19.3 \pm 5$ & Crushing & $0.017 \pm 0.02$ & $0.0035 \pm 0.005$ & $0.021 \pm 0.02$ & $1.21 \pm 0.82$ & $2.99 \pm 0.41$ \\
\hline B & $52.5 \pm 24$ & $90.0 \pm 24$ & $9 \pm 1.15$ & Buldging & $0.014 \pm 0.01$ & $0.0043 \pm 0.004$ & $0.018 \pm 0.01$ & $1.30 \pm 0.76$ & $2.05 \pm 0.30$ \\
\hline $\mathrm{C}$ & $106.7 \pm 52$ & $173.3 \pm 52$ & $19.8 \pm 3.8$ & Bridging & $0.03 \pm 0.02$ & $0.012 \pm 0.01$ & $0.041 \pm 0.04$ & $1.41 \pm 0.70$ & $7.17 \pm 0.20$ \\
\hline $\mathrm{D}$ & $34.7 \pm 12$ & $55.0 \pm 12$ & $6 \pm 0$ & Tensile & $0.016 \pm 0.01$ & $0.004 \pm 0.003$ & $0.02 \pm 0.01$ & $1.23 \pm 0.81$ & $1.13 \pm 0.17$ \\
\hline E & $95.0 \pm 32$ & $153.3 \pm 32$ & $18 \pm 2$ & Tensile & $0.03 \pm 0.02$ & $0.009 \pm 0.008$ & $0.036 \pm 0.003$ & $1.31 \pm 0.74$ & $2.23 \pm 1.01$ \\
\hline $\mathrm{F}$ & $39.7 \pm 17$ & $65.0 \pm 17$ & $7.3 \pm 1.15$ & Bridging & $0.005 \pm 0.008$ & $0.005 \pm 0.004$ & $0.011 \pm 0.012$ & $1.57 \pm 0.67$ & $1.79 \pm 0.75$ \\
\hline
\end{tabular}

Note: Sample size $=3$

$2 \%$ and $5 \%$ sisal fibres, respectively, as compared to plain sample. The maximum load was noted to be $8 \%$ higher for the $2 \%$ sisal fibre sample only as compared with the plain sample. This could be due to the high tensile strength of sisal fibre and the better bond with the cementitious matrix. In comparison withthe compressive strength of the plain mortar sample to $2 \%$ sisal fibre sample, a3\% increment was observed, whereas in all other cases reduction in compressive strength for fibrous samples was noted as compared with that of the plain mortar sample. This was consistent with the finding of many studies $(13,30)$ where addition of fibre resulted in reduction of compressive strength, mainly due to decrease in the density of sample and because ofthe creation of voids due to the presence of fibre. The diameter/width of rice straw was greater than that of sisal fibre. Therefore greater reduction in compressive strength was observed in rice straw samples. The CEp of all samples A to $F$ was calculated as $0.017 \mathrm{MJ} / \mathrm{m}^{3}$,
$0.014 \mathrm{MJ} / \mathrm{m}^{3}, 0.03 \mathrm{MJ} / \mathrm{m}^{3}, 0.016 \mathrm{MJ} / \mathrm{m}^{3}, 0.03 \mathrm{MJ} /$ $\mathrm{m}^{3}$ and $0.005 \mathrm{MJ} / \mathrm{m}^{3}$, respectively, which showed significant improvement of $76 \%$ for both $2 \%$ and $5 \%$ sisal fibre samples as compared with that of the plain mortar sample. The PEp of plain and fibrous samples A to F wasrecorded as $0.0035 \mathrm{MJ} /$ $\mathrm{m}^{3}, 0.0043 \mathrm{MJ} / \mathrm{m}^{3}, 0.012 \mathrm{MJ} / \mathrm{m}^{3}, 0.004 \mathrm{MJ} / \mathrm{m}^{3}$, $0.009 \mathrm{MJ} / \mathrm{m}^{3}$ and $0.005 \mathrm{MJ} / \mathrm{m}^{3}$ respectively. This also indicated an increment of 2.21 and 1.57 times for $2 \%$ and $5 \%$ sisal fibre samples respectively, as compared with the plain mortar sample. The TEp of samples A to $\mathrm{F}$ was observed as $0.021 \mathrm{MJ} / \mathrm{m}^{3}$, $0.018 \mathrm{MJ} / \mathrm{m}^{3}, 0.041 \mathrm{MJ} / \mathrm{m}^{3}, 0.02 \mathrm{MJ} / \mathrm{m}^{3}, 0.036 \mathrm{MJ} /$ $\mathrm{m}^{3}$ and $0.011 \mathrm{MJ} / \mathrm{m}^{3}$ respectively. This showed $95 \%$ and $71 \%$ improvement for $2 \%$ and $5 \%$ sisal fibre samples respectively, as compared with that of the plain sample. The compressive toughness index showed values of 1.41 and 1.31 for $2 \%$ and $5 \%$ sisal fibres respectively, and 1.30 and 1.23 for $2 \%$ and $5 \%$ rice straw samples respectively, as compared with 1.21 for the plain mortar sample, which was 


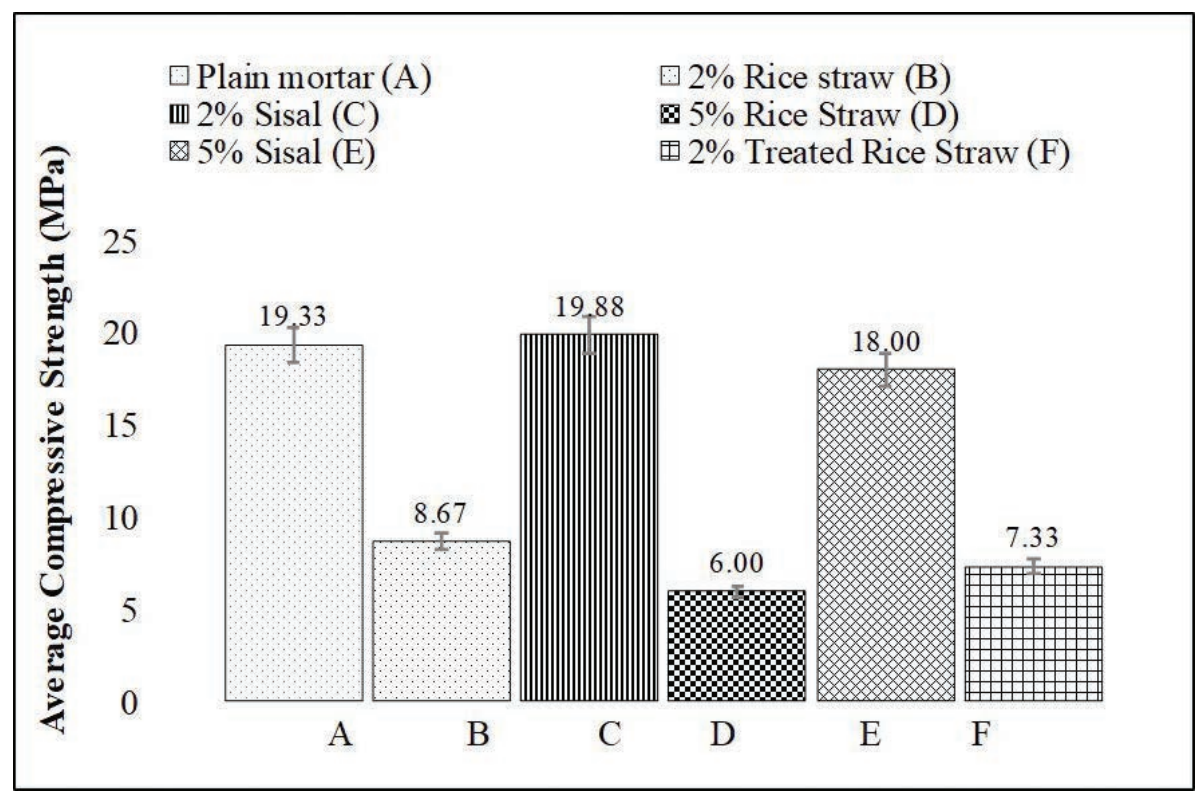

FIGURE 7. Comparison of compressive properties of fibre reinforced mortar.

the indication of fibre bridging which helped in limiting the size of cracks and provided enhanced resistance to stresses after the initiation of cracks.

Comparison of compressive strength of plain and fibrous mortar samples is shown in Figure 7. The reduction of 2.1 times, 3.16 times and 2.71 times was noted for $2 \%$ rice straw, $5 \%$ rice straw and $2 \%$ treated rice straw, respectively, as compared with plain samples. However, a $6 \%$ increment was found with the addition of $2 \%$ sisal fibre than the plain mortar sample, whereas a $5 \%$ reduction in compressive strength was observed in the 5\% sisal fibre mortar sample. This showed that the content and type of fibre influenced the compressive strength of properties and lowering the content of fibre could increase compressive strength.

\subsubsection{Modulus of elasticity of mortar cubes}

Modulus of elasticity $E_{p}$ was calculated as the ratio of stress change to strain change within elastic limits. The averaged $E_{p}$ of samples $A$ to $F$ is given in Table 7. The $\mathrm{E}_{\mathrm{p}}$ for plain mortar was $2.99 \mathrm{GPa}$ and for $2 \%$ and $5 \%$ rice straw it was $2.05 \mathrm{GPa}$ and 1.13 GPa respectively. This showed a $31 \%$ and $62 \%$ reduction thanthe plain mortar sample. For the treated $2 \%$ rice straw sample the value of $\mathrm{E}$ was $1.79 \mathrm{GPa}$. This showed a $40 \%$ reduction than the plain sample. The value of $\mathrm{E}$ for the $2 \%$ and $5 \%$ sisal fibre samples was calculated to be $7.17 \mathrm{GPa}$ and $2.23 \mathrm{GPa}$. This showed 1.39 times increment in the $2 \%$ sisal fibre sample, a $25 \%$ reduction in the $5 \%$ sisal fibre sample as compared with the plain sample. It can be observed that, as with other properties, the $2 \%$ sisal fibre sample showed best values for modulus of elasticity as compared with plain and rice-straw mortar samples due to its high tensile properties and lower fibre content.

\subsection{Compressive properties of ISSB}

\subsubsection{Compressive behaviour of ISSB}

The compressive stress-strain curves are shown in Figure 8(a-c) for each sample of single block, $1 * 2$ blocks ( 1 block wide and 2 blocks high) and $2 * 2$ blocks ( 2 blocks wide and 2 blocks high). Singleblock samples showed higher stress and strain as compared with the other two sets of blocks. The reduction in stress-strain of the $1 * 2$ blocks and $2 * 2$ blocks compared with the single block might have been due to interlocking interaction between the different block units. Figure 9(a-c) shows the fractured mechanism of tested samples. Figure 9a shows the fracture surface of the single block sample and shear/vertical cracks can be observed in the region of interlocking. This is due to stress peak in the interlocking region where the resistance area is found to be smaller than in the rest of the block. Figures $9 \mathrm{~b}$ and $9 \mathrm{c}$ show the failure of $1 * 2$ blocks and $2 * 2$ blocks, which indicates crack development at an inclined angle and not on the joints. This led to blocks' failing through crushing by opening of small gaps on individual blocks and finally initiation of cracks without opening up of joints. This could be due to the efficiency of interlocking mechanism of the blocks. 

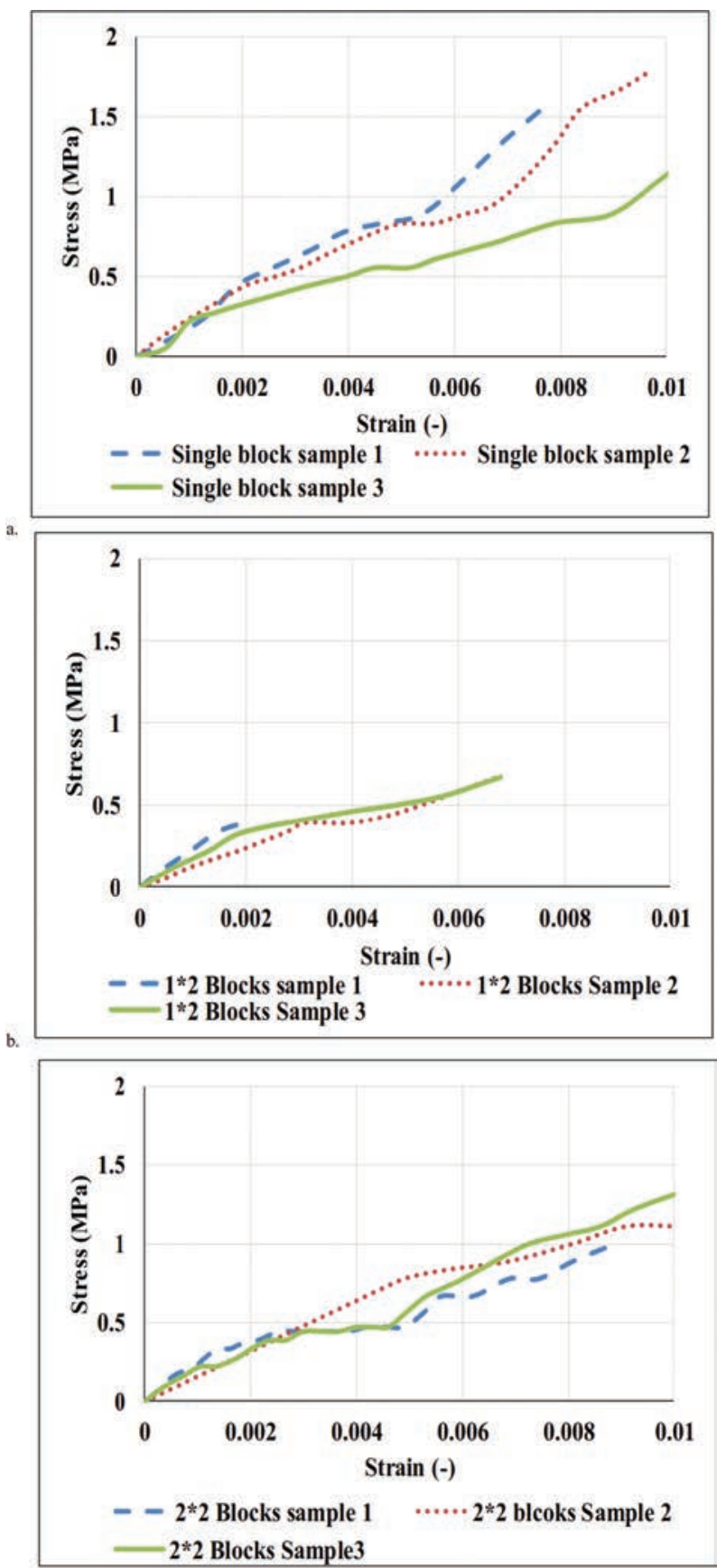

c.

FIgure 8. Stress strain of ISSBs, a. Single block, b. $1 \times 2$ blocks, and c. $2 \times 2$ blocks.

\subsubsection{Compressive strength, compressive prelpost crack, absorbed energies and compressive toughness index of ISSB}

The compressive strength was taken as the peak value of stress from stress strain curve of ISSB. The area below the stress-strain curve up to the stress of first crack was defined as the pre-crack absorbed energy $\mathrm{PE}_{\mathrm{b}}$. The area below the stress-strain curve from the first crack stress to maximum load was regarded as the post-crack energy absorbed $(\mathrm{CE})_{\mathrm{b}}$. The total area below the stress-strain curve from initial to maximum load was categorised as the total energy absorbed (TE) $)_{b}$. The ratio of total energy absorbed and first-crack energy absorbed was taken as the compressive toughness index $(\mathrm{CTI})_{\mathrm{b}}$. Table 8 shows the values of first-crack load, maximum load, compressive strength, $\mathrm{PE}_{\mathrm{b}}, \mathrm{CE}_{\mathrm{b}}, \mathrm{TE}_{\mathrm{b}}$ and $\mathrm{CTI}_{\mathrm{b}}$ of samples for single block, $1 * 2$ blocks and $2 * 2$ blocks. The first crack load of $11.7 \mathrm{kN}, 34.8 \mathrm{kN}$, and 51.1 $\mathrm{kN}$ were found for single block, $1 * 2$ block and $2 * 2$ block samples respectively. Maximum loads of 20 $\mathrm{kN}, 72.5 \mathrm{kN}$ and $105 \mathrm{kN}$ were recorded for single block, $1 * 2$ blocks and $2 * 2$ blocks samples respectively. The values for first-crack and maximum loads were increased by 3-4 times as the number of blocks increased with better load distribution area. The compressive strengths of single block, $1 * 2$ blocks and $2 * 2$ blocks samples were noted as $1.53 \mathrm{MPa}$, $0.83 \mathrm{MPa}$, and $0.92 \mathrm{MPa}$ respectively. Comparing compressive strength of a single block with $1 * 2$ blocks and $2 * 2$ blocks a reduction of $45 \%$ and $39 \%$ respectively was noted. This decrease could be due to a slenderness effect of the samples with more than one block. This also compared well with the fact that as the sample height increased the compressive strength reduced, which was also reported by other researchers (3). Comparison of average compressive strengths of each sample is shown in Figure 10.

The $\mathrm{CE}_{\mathrm{b}}$ of three specimen configurations (single block, $1 * 2$ blocks and $2 * 2$ blocks) was calculated as $0.006 \mathrm{MJ} / \mathrm{m}^{3}, 0.002 \mathrm{MJ} / \mathrm{m}^{3}$ and $0.006 \mathrm{MJ} / \mathrm{m}^{3}$ respectively, which showed significant improvement of $66 \%$ for $1 * 2$ blocks specimen over the single block and no difference was observed in $2 * 2$ blocks specimen. This increment for $1 * 2$ blocks specimen was due to efficiency of interlocking interface between two blocks. The $\mathrm{PE}_{\mathrm{b}}$ of three specimen configurations was

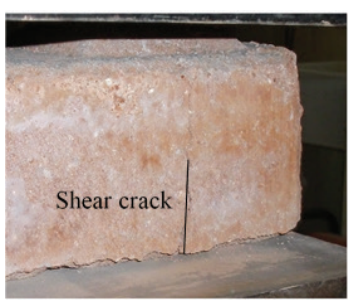

a.

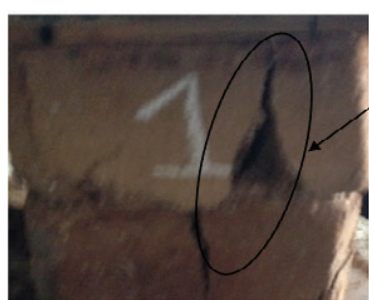

b.

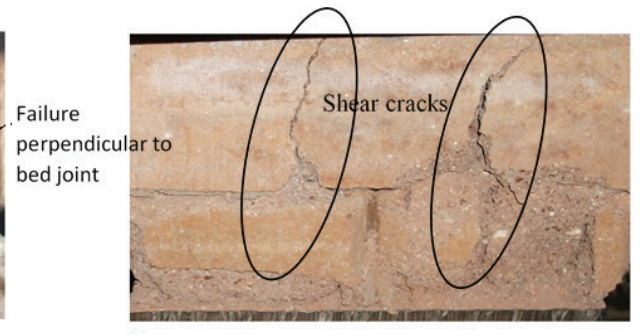

c.

FiguRE 9. Fractured surfaces in blocks: a. Single block, b. 1x2 blocks, and c. $2 \times 2$ blocks. 


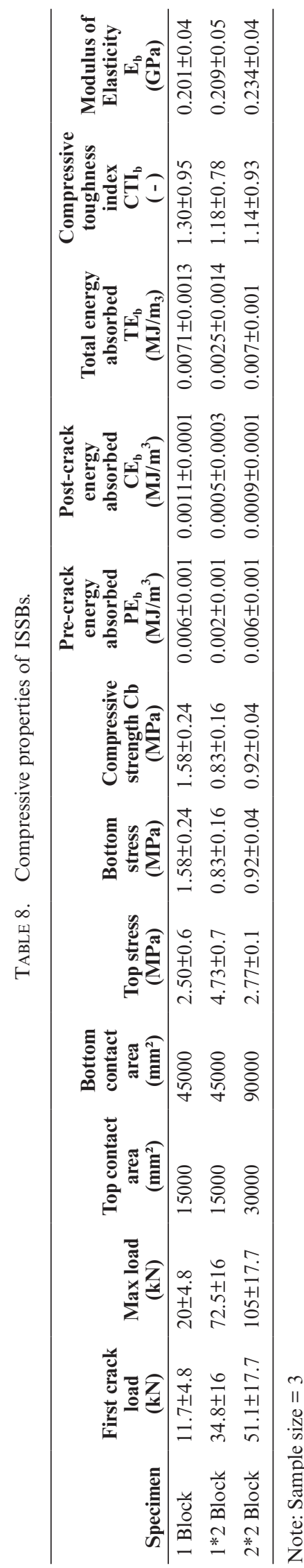

recorded as $0.0011 \mathrm{MJ} / \mathrm{m}^{3}, 0.0005 \mathrm{MJ} / \mathrm{m}^{3}$ and 0.0009 $\mathrm{MJ} / \mathrm{m}^{3}$, respectively. This had indicated $54 \%$ and $18 \%$ reduction in post-crack energy absorbed for $1 * 2$ and $2 * 2$ blocks specimens respectively, as compared with single block. This showed that the interlocking mechanism did not perform well after crack propagation. A similar outcome was observed for the values of $\mathrm{TE}_{\mathrm{b}}$ and $\mathrm{CTI}_{\mathrm{b}}$, which showed a reduction of $64 \%$ for $\mathrm{TE}_{\mathrm{b}}$ as compared with single block and a reduction of $13 \%$ for $\mathrm{CTI}_{\mathrm{b}}$ as compared with single block. This proved that the interlocking mechanism did not perform efficiently after the propagation of cracks and required inclusion of another component like plaster to improve post-crack behaviour.

\subsubsection{Modulus of elasticity of ISSB}

Modulus of elasticity $\left(\mathrm{E}_{\mathrm{b}}\right)$ was calculated as the ratio of stress change to strain change. The $E_{b}$ is detailed for each specimen in Table 8. It was found that the value of $\mathrm{E}_{\mathrm{b}}$ for the single-block sample was $0.201 \mathrm{GPa}$ and for $1 * 2$ blocks and $2 * 2$ blocks specimens it was calculated as $0.209 \mathrm{GPa}$ and $0.234 \mathrm{GPa}$ respectively. This showed a $4 \%$ and $16 \%$ increase from that of the single- block specimen, which was an indication of the interlocking mechanism capacity's taking more deformation than was the case with the single-block specimen.

\subsection{Microscopic analysis}

\subsubsection{Surface images of fibres}

Natural fibres have different chemical composition depending on variation in cultivation techniques, soil and environment. Pretreatment of fibres like washing with tap water and retention in boiling water affects their properties. Morphological changes in the fibres were observed using Bruker 3D optical microscope. Figure 11 (a-c) shows the surface images of sisal, rice straw and treated rice straw. It was observed that treated rice straw had a smoother surface than sisal and untreated rice straw, which resulted in a poor bond between mortar and treated fibre. This was evident from the lowest strength of the treated rice-straw sample as compared with all other samples. It was also noted from Figures $11 \mathrm{a}$ and $11 \mathrm{~b}$ that surface profile for sisal was higher than that of rice straw, giving a high value of surface roughness, which could be an important factor in developing good bond between sisal and cementitious material.

\subsubsection{Surface images of fibrous and plain-mortar cube samples}

Figure 12 (a-d) shows the microscopic images of plain and fibrous mortar cube samples. These samples were produced from the cube samples after 


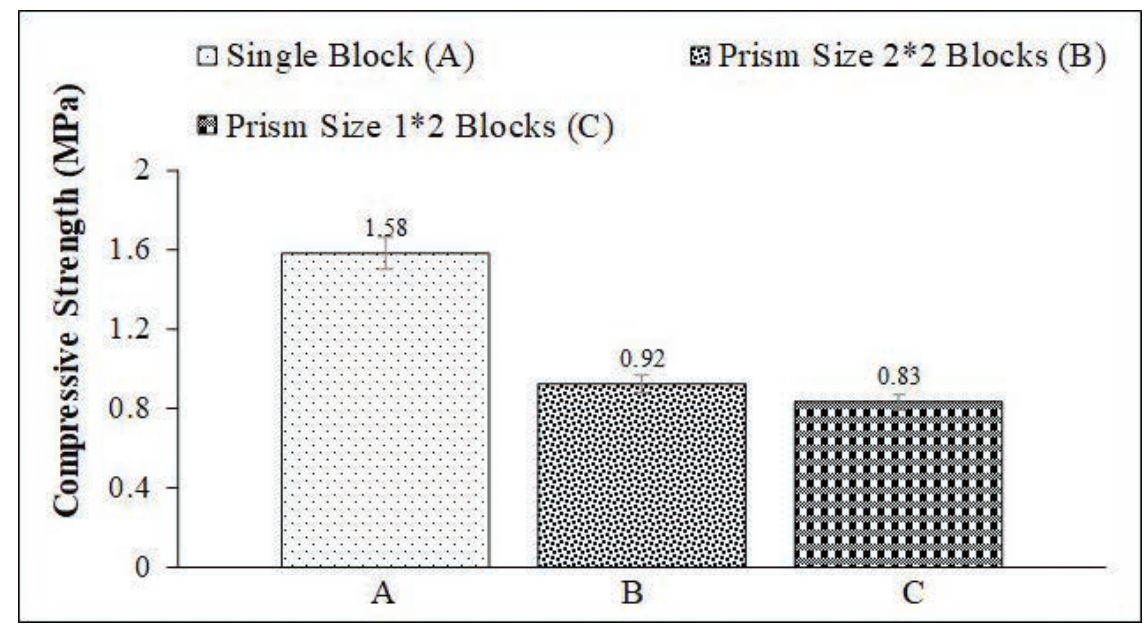

FIGURE 10. Comparison of compressive strength of blocks.
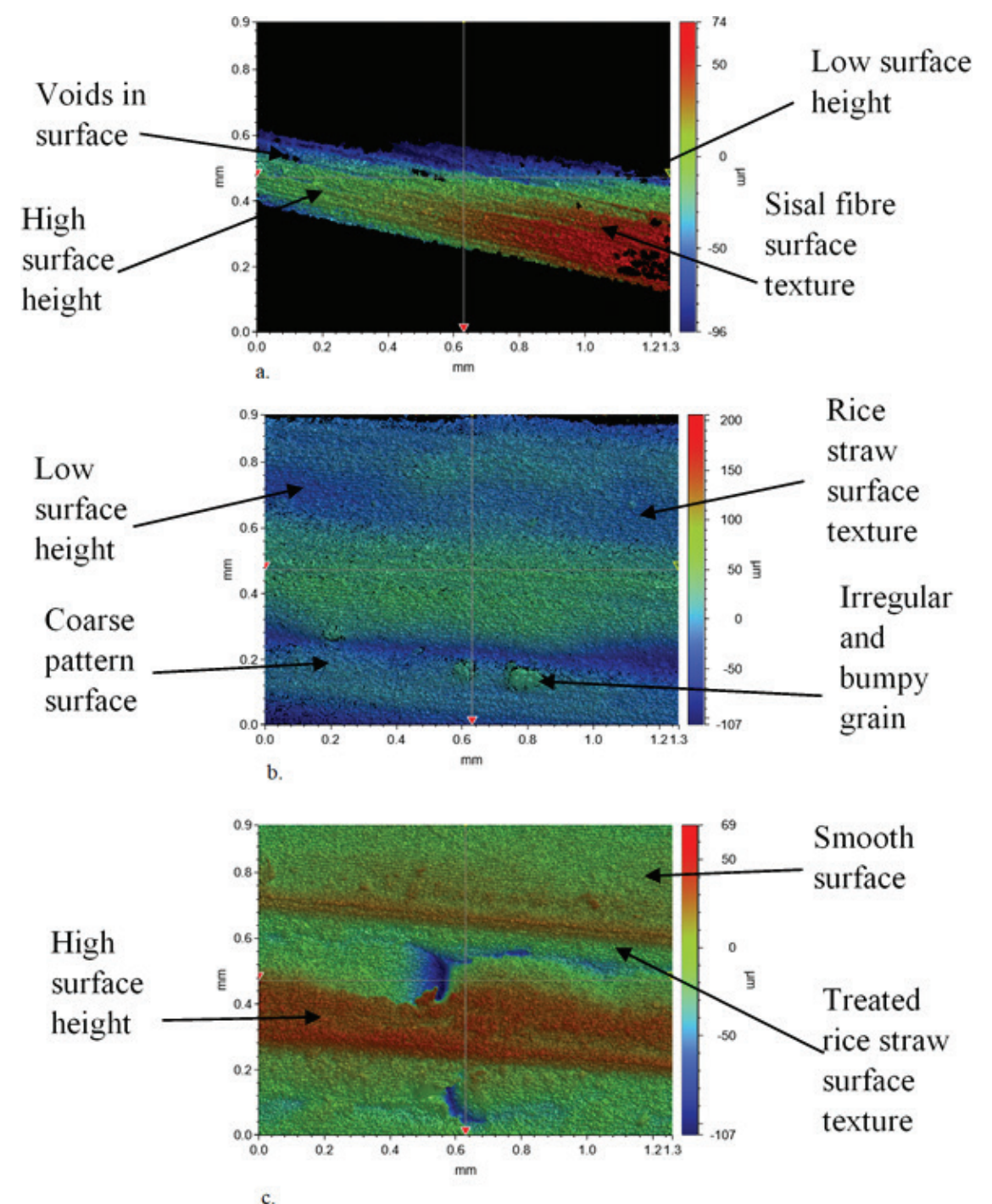

FiguRE 11. Surface contour of fibres, a. Sisal fibre surface roughness, b. Rice straw surface roughness, and c. Treated rice straw surface roughness. 

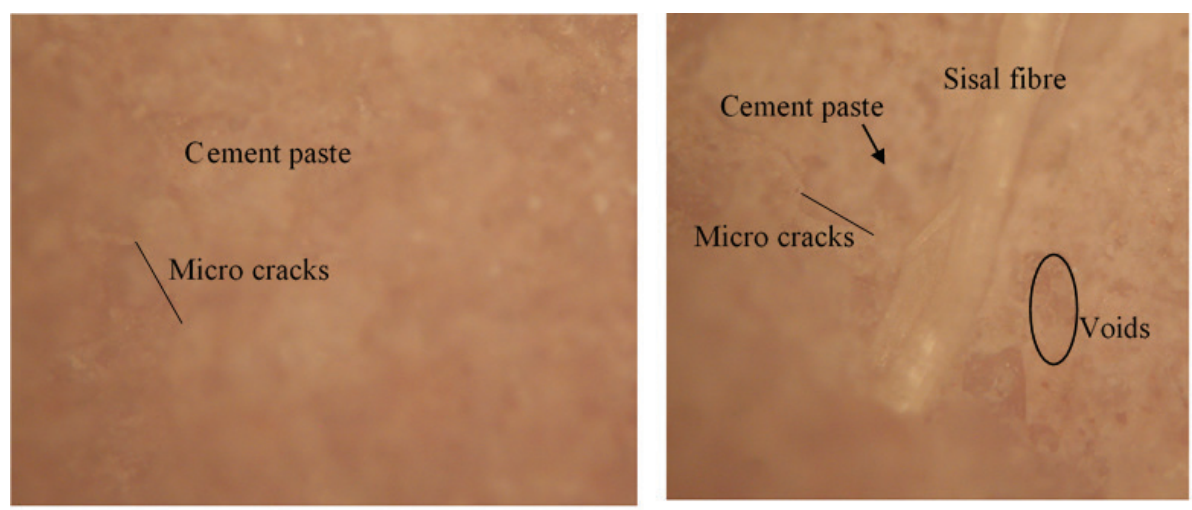

a.

b.
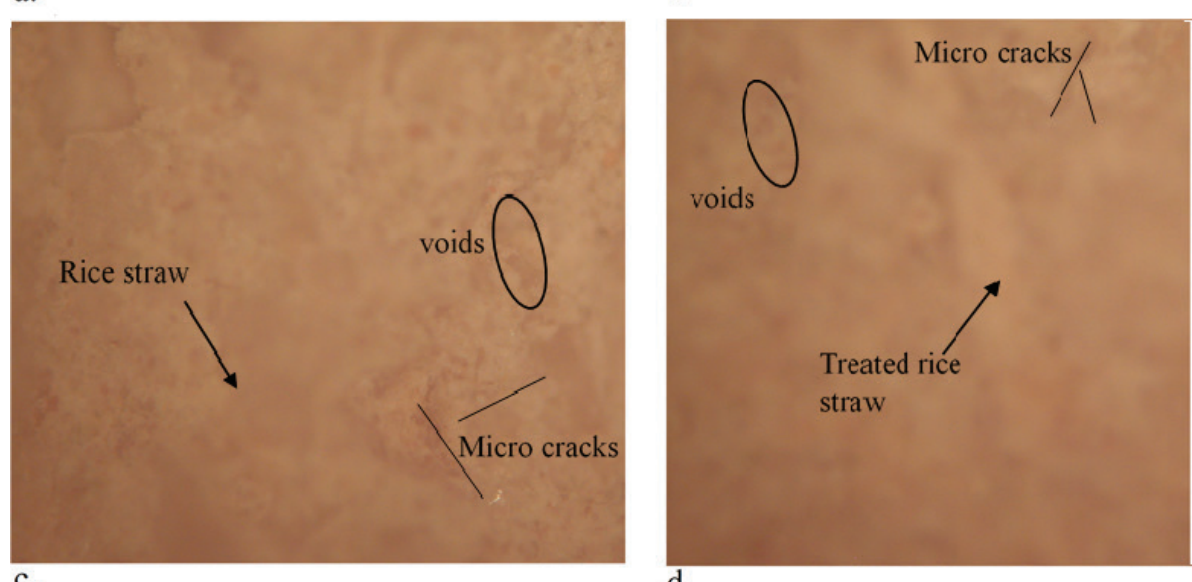

d.

FIGURE 12. Microscopic images from mortar cubes, a. Plain mortar surface texture, b. Sisal fibre embedment in mortar, c. Rice straw embedment in mortar, and d. Treated rice straw embedment in mortar.

carrying out compression testing. Figure $12 \mathrm{a}$ shows micro cracks in the cement paste. In Figure 12b a sample of sisal-fibre mortar cube shows the embedment of sisal fibre in cement paste without any gap or void, indicating a proper bond of fibre in the cement matrix. This resulted in better mechanical properties in sisal fibrous cubes than in other samples. Figures 12c and 12d show the untreated and treated rice-straw samples respectively, which indicated the presence of micro cracks and voids in the cement paste and a loose bond with rice straw. This poor bond and void resulted in reduced post-crack performance and toughness.

\section{DISCUSSION}

\subsection{Relationship between material properties and low-cost house performance}

In low-cost masonry housing main-component walling is mostly employed to resist compressive and lateral load $(31,32,33)$. Therefore, the structural performance of the wall under these loadings is of prime importance. This depends on the characteristics and mechanical properties of the materials used, which include compressive strength, modulus of elasticity, pre/post/total energy absorption capacity (PE and $\mathrm{CE}$, respectively) and toughness (CTI). Therefore, it is important to explore the best mechanical properties of material to enhance the performance of walling and in essence overall performance of masonry house. In this study mechanical properties of plain and fibrous mortar cube samples and ISSBs were examined. The addition of $2 \%$ sisal fibre cube samples showed the most promising results, indicating a 3\% increment in compressive strength, 76\% increment in $\mathrm{PE}_{\mathrm{p}}, 2.21$ times increase in $\mathrm{CE}_{\mathrm{p}}, 95 \%$ increase in $\mathrm{TE}_{\mathrm{p}}$ and $17 \%$ increase in $\mathrm{CTI}_{p}$ as compared with the plain mortar cube samples. For ISSB there was a $45 \%$ and $39 \%$ reduction in compressive strength for $1 * 2$ and $2 * 2$ blocks respectively, as compared with single block. In other mechanical properties like $\mathrm{CE}_{\mathrm{b}}$ a $66 \%$ improvement was observed. The values of $\mathrm{PE}_{\mathrm{b}}, \mathrm{TE}_{\mathrm{b}}$ and $\mathrm{CTI}_{\mathrm{b}}$ for $1 * 2$ and $2 * 2$ blocks were reduced by $54 \%, 64 \%$ and $13 \%$ respectively, as compared with those of single block. This shows that the use of mortar with $2 \%$ sisal fibre for interlocking structure is likely to give optimised mechanical properties and hence improve the overall performance of masonry structure. 


\subsection{Empirical equations}

\subsubsection{Empirical relation between modulus of elasticity and compressive strength of mortar cubes}

The following empirical equations [1-2] were developed (Figure 13) with the help of averaged experimental data. These equations are based on limited data (only three values) in order to check the trend of variation due to addition of different content of fibre. These are established by means of best fit curve ( $\mathrm{R}^{2}$ ranging from 0.90 to 1.0$)$ with the simplification of coefficients and exponents of input variables numerically to predict the modulus of elasticity (E) in GPa:

$$
\begin{gathered}
E=0.3 * C^{0.8^{*} K} \\
E=(4+K) * Y * C^{2}-160 * Y * C+1492
\end{gathered}
$$

where $\mathrm{C}$ is compressive strength in $\mathrm{MPa}$ and $\mathrm{K}=1,1.1$ and 0.95 for plain, $2 \%$ rice straw and $5 \%$ rice straw specimen respectively in equation [1]. For equation [2], $\mathrm{K}(\mathrm{GPa})=0.293,0.294$ and 0.291 for plain, $2 \%$ sisal and 5\% sisal fibre reinforced mortar, respectively, $\mathrm{Y}\left(1 / \mathrm{MPa}^{2}\right)=1$ and $\mathrm{Z}(\mathrm{GPa} / \mathrm{MPa})=1$. It may be noted that for each value an average of three readings is taken. In the case of sisal-reinforced mortar a convex quadratic increase is observed, whereas in rice- reinforced mortar a powered linear increase is found.

Table 9 details the experimental and empirical values of modulus of elasticity (GPa). It can be seen that a correlation holds between compressive strength and modulus of elasticity and these being directly proportional. This direct relationship is attributed to the capacity to take greater load, which is increased due to the presence of fibre of high tensile strength and the bridging phenomenon. It can therefore be stated that an increase in compressive strength results in higher value of modulus of elasticity. Figure 14 compares the experimental and numerical values of modulus of elasticity in plain and fibrous samples. It can be seen that the values of E obtained from equations [1] and [2] are very close to the experimental values. There is good agreement between empirical and experimental values. The percentage errors are 3.7\%, 1.2-3.6\% and $2.4 \%-3.5 \%$ for plain, rice-straw and sisal mortar samples respectively.

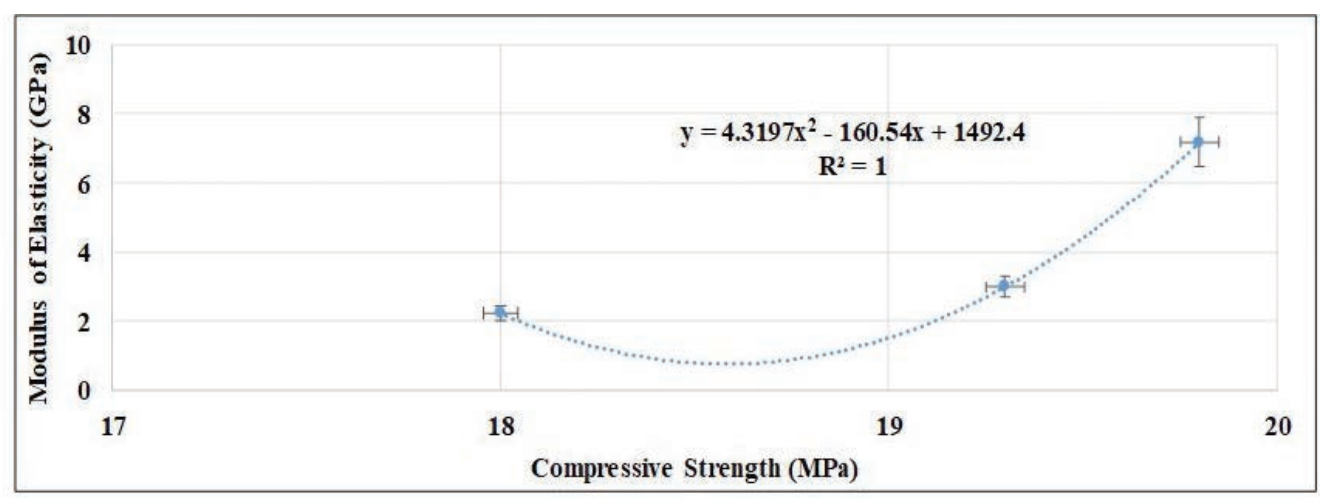

a.

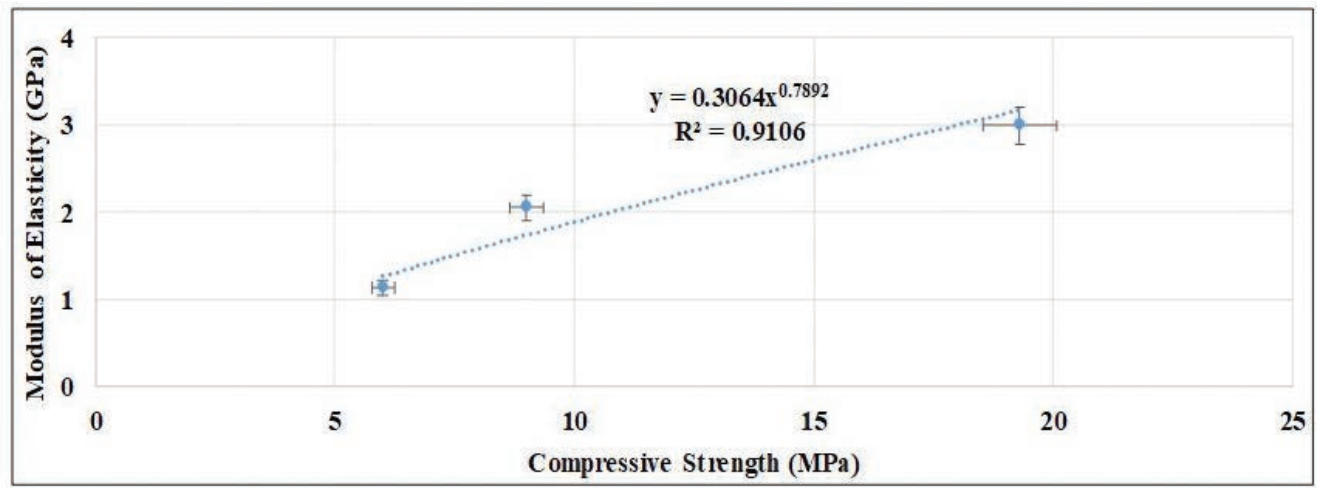

b.

FIGURE 13. Development of empirical equation for modulus of elasticity, a. Sisal reinforced mortar, b. Rice straw reinforced mortar. 
TABLE 9. Experimental and theoretical values of Modulus of Elasticity for plain and fibrous mortar

\begin{tabular}{lcccc}
\hline & \multirow{2}{*}{$\begin{array}{c}\text { Compressive } \\
\text { Specimen }\end{array}$} & \multicolumn{3}{c}{ Modulus of Elasticity $\mathbf{E}_{\mathbf{p}}(\mathbf{G P a})$} \\
\cline { 3 - 5 } & Strength C $\mathbf{p}(\mathbf{M P a})$ & Empirical Equation & Experimental & Error (\%age) \\
\hline Plain Mortar & 19.3 & 3.10 & 2.99 & $3.7 \%$ \\
2\% Rice Straw Reinforced Mortar & 9 & 2.07 & 2.05 & $1.2 \%$ \\
5\% Rice Straw Reinforced Mortar & 6 & 1.17 & 1.13 & $3.6 \%$ \\
2\% Sisal Fibre Reinforced Mortar & 19.8 & 7.42 & 7.17 & $3.5 \%$ \\
5\% Sisal Fibre Reinforced Mortar & 18 & 2.28 & 2.23 & $2.4 \%$ \\
\hline
\end{tabular}

Note: $1 . E=0.3 * C^{0.8 * K}$; Where $\mathrm{K}=1,1.1 \& 0.95$ for plain, $2 \%$ rice straw and $5 \%$ rice straw specimen, respectively. $2 . E=(4+K) * Y *$ $C^{2}-160 * Z * C+1492$; Where K $(\mathrm{GPa})=0.293,0.294 \& 0.291$ for plain, $2 \%$ sisal and $5 \%$ sisal specimen, respectively, $\mathrm{Y}\left(1 / \mathrm{MPa}^{2}\right)=1$ and $\mathrm{Z}(\mathrm{GPa} / \mathrm{MPa})=1$ for all cases.

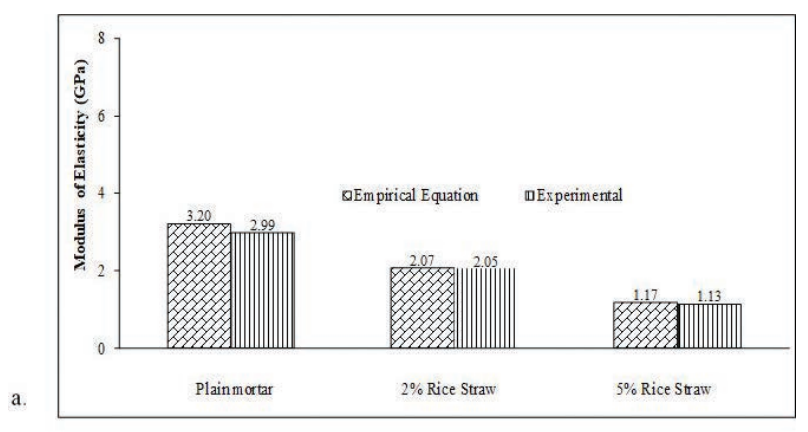

b.

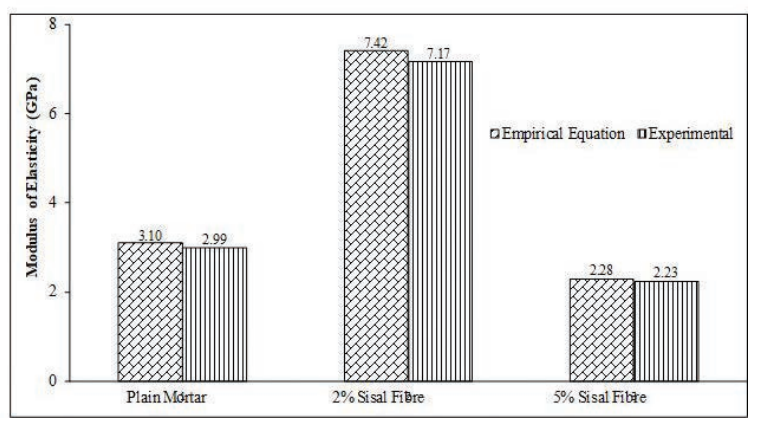

FIGURE 14. Comparison of modulus of elasticity with experimental and empirical values for plain and fibrous mortar a. Equation 1 b. Equation 2.

\subsubsection{Empirical relation between modulus of elasticity and compressive strength of ISSB}

The following empirical equation [3] is developed (Figure 15) with the help of averaged experimental data. This equation is based on nine samples of blocks representing three no. of samples for single block, $1 * 2$ and $2 * 2$ blocks respectively. This is established by means of best fit curve $\left(\mathrm{R}^{2}=1.0\right)$ with the simplification of coefficients and exponents of input variables numerically to predict the modulus of elasticity (E) in GPa:

$$
E=-0.4 * K^{*} Z * C^{2}+Z * C-0.4
$$

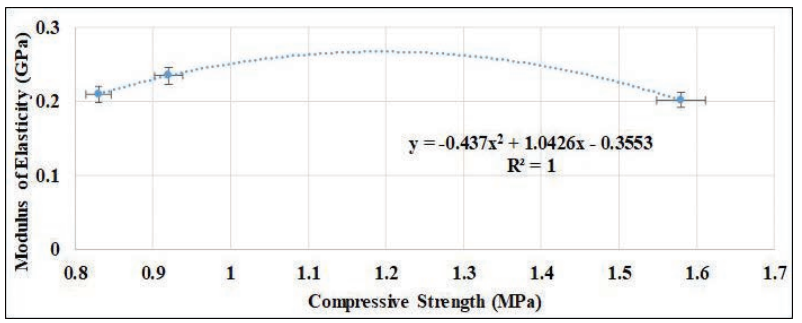

FiguRE 15. Development of empirical equation for modulus of elasticity of blocks.

where $\mathrm{C}$ is compressive strength in $\mathrm{MPa}$ and $\mathrm{K}$ $(1 / \mathrm{MPa})=0.98,0.65,0.60$ and $\mathrm{Z}(\mathrm{GPa} / \mathrm{MPa})=1$, $0.95,0.9$ for single block, $1 * 2$ and $2 * 2$ blocks respectively. As far as the behaviour of blocks is concerned, empirical modelling reveals that there is concave variation among single blocks, $1 * 2$ blocks and $2 * 2$ blocks.

Table 10 details the experimental and empirical values of modulus of elasticity (GPa) of ISSB. It can be seen that compressive strength and modulus of elasticity of ISSB are correlative and are inversely proportional. This inverse proportionality is due to the different configuration of blocks. The reduction in compressive strength and increase in modulus of elasticity of other configurations as compared with single block is due to block interface joint which leads to large displacements. Therefore it can be stated that a decrease in compressive strength results in a higher value of modulus of elasticity. Figure 16 compares the experimental and numerical values of modulus of elasticity for single block, $1 * 2$ and $2 * 2$ blocks. It can be seen that the values of E obtained from equation [3] are very close to the experimental values. The percentage error is $0.7 \%-6.6 \%$ for different block configurations.

\section{CONCLUSIONS}

The mechanical properties (compressive strength, modulus of elasticity, pre and post crack energy absorbed and toughness index) of interlocking 
TABLE 10. Experimental and theoretical values of Modulus of Elasticity for ISSBs

\begin{tabular}{|c|c|c|c|c|}
\hline \multirow[b]{2}{*}{ Sample Symbol } & \multirow{2}{*}{$\begin{array}{c}\text { Compressive } \\
\text { Strength } \mathrm{C}_{\mathrm{b}}(\mathrm{MPa})\end{array}$} & \multicolumn{3}{|c|}{ Modulus of Elasticity $E_{b}(G P a)$} \\
\hline & & Empirical Equation & Experimental & Error (\%age) \\
\hline Single Block & 1.58 & 0.20 & 0.20 & $0.7 \%$ \\
\hline $1 * 2$ Block & 0.83 & 0.22 & 0.21 & $4.0 \%$ \\
\hline $2 * 2$ Block & 0.92 & 0.25 & 0.23 & $6.6 \%$ \\
\hline
\end{tabular}

Note: $1 . E=-0.4 * K * Z * C^{2}+Z * C-0.4$; Where $\mathrm{K}(1 / \mathrm{MPa})=0.98,0.65,0.60$ and $\mathrm{Z}(\mathrm{GPa} / \mathrm{MPa})=1,0.95,0.9$ for single block, $1 * 2$ block and $2 * 2$ block, respectively.

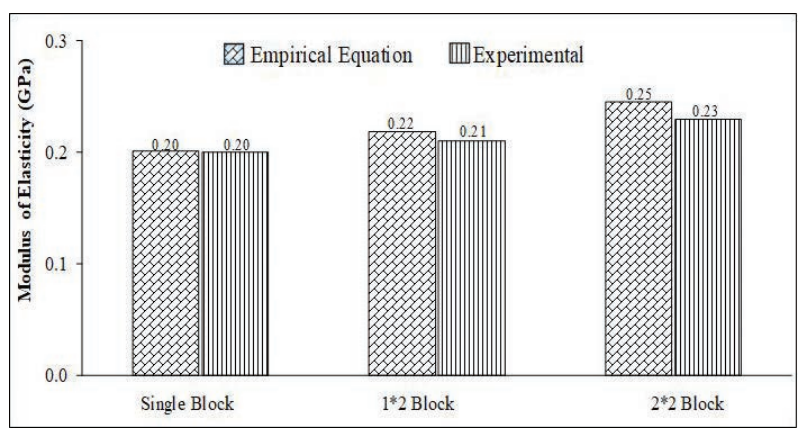

FIGURE 16. Comparison of modulus of elasticity with experimental and empirical (equation 3) values for blocks.

soil-stabilised blocks and fibrous/non-fibrous mortar were experimentally investigated to determine how best to enhance the performance of proposed interlocked fibrous plastered (i.e. reinforced coating) low-cost housing. The following conclusions are drawn:

1. A knowledge gap identified from the literature review regarding the mechanical properties (compressive strength, modulus of elasticity, pre/post crack energy absorbed and toughness) of ISSB and fibrous mortar which are prime parameters of enhancing resistance to lateral load like wind and earthquake for a masonry structure.

2. Surface contours of sisal fibres showed a smooth surface, whereas rice-straw fibres exhibited a rough and irregular bumpy surface indication the presence of impurities.

3. The failure modes of the fibrous cubes were characterised by a bridging, buldging effect and tensile cracks due to the presence of natural fibres, as compared with crushing failure of plain samples. $2 \%$ and $5 \%$ sisal fibres samples showed very high stiffness at first crack load and ductility at ultimate load, as compared with all other samples.

4. Mechanical properties with $2 \%$ sisal-fibre mortar specimens resulted in an increase of $17 \%$, $8 \%, 3 \%, 76 \%, 221 \%, 17 \%$ and $139 \%$ of first crack load, maximum load, $\mathrm{PE}_{\mathrm{p}}, \mathrm{CE}_{\mathrm{p}}, \mathrm{TE}_{\mathrm{p}}$,
$\mathrm{CTI}_{\mathrm{p}}$ and $\mathrm{E}_{\mathrm{p}}$ respectively, as compared with that of plain mortar specimen.

5. The compressive strength of $2 \%$ rice-straw, $5 \%$ rice-straw and $2 \%$ treated rice-straw reinforced mortar resulted in a reduction of $210 \%, 316 \%$ and $271 \%$ respectively. A $6 \%$ increment was found with the addition of $2 \%$ sisal fibre from a plain mortar sample and a $5 \%$ reduction in compressive strength was observed in a $5 \%$ sisal-fibre mortar sample

6. Microscopic images of sisal-fibre mortar cube showed the embedment of sisal fibre in cement paste without any gap or void, indicating a proper bond of fibre in cement matrix. This resulted in better mechanical properties in sisal- fibrous cubes than in other samples. Untreated and treated rice-straw samples indicated the presence of micro cracks and voids in the cement paste and loose bond with rice straw. This poor bond and void resulted in reduced pre/post crack performance and toughness.

7. The failure modes of the ISSBs were characterised either by failure perpendicular to bed joint or shear cracks and spalling of block. The compressive stress- strain curves for each sample of single block showed higher stress and strain than did the other two sets of blocks. The reduction in stress-strain of the $1 * 2$ and $2 * 2$ blocks as compared with the single block might have been due to interlocking interaction between the different block units.

8. The mechanical properties of $1 * 2$ blocks were compared with single block and 1.97 times, 2.62 times and 4\% increase was found in first crack, maximum load and modulus of elasticity respectively. Values of compressive strength, $\mathrm{PE}_{\mathrm{b}}, \mathrm{TE}_{\mathrm{b}}$ and $\mathrm{CTI}_{\mathrm{b}}$ were reduced by $47 \%, 67 \%$, $64 \%$ and $9 \%$ respectively.

9. With $2 * 2$ blocks 3.36 times, 4.25 times and $16 \%$ increase was found in first crack, maximum load and modulus of elasticity respectively. Values of compressive strength, $\mathrm{PE}_{\mathrm{b}}, \mathrm{TE}_{\mathrm{b}}$ and $\mathrm{CTI}_{\mathrm{b}}$ were reduced by $41 \%, 1 \%, 1.5 \%$ and $12 \%$ respectively, as compared with those of single ISSB.

10. Empirical relations were developed with the help of experimental data for prediction of modulus of elasticity for fibrous/ plain mortar 
samples and interlocking soil - stabilised blocks. The experimental and empirical values were found close enough, with a maximum error of $6.6 \%$ in ISSBs and $3.7 \%$ in mortar cube samples.

In light of the findings and observed behaviour the addition of $2 \%$ sisal fibre in plaster (i.e. reinforced coating) of interlocked masonry walling is likely to be effective in improving the performance including the lateral resistance of low-cost masonry house. Further investigation is required to evaluate the performance of ISSB column or wall with fibrereinforced plaster when subjected to lateral load like wind and earthquake.

\section{ACKNOWLEDGEMENTS}

The authors would like to thank B Chilla \& H Hatibu (NHBRA) and organizations who helped them throughout this research work which was funded by Energy and Low Income Tropical Housing Project (ELITH). The careful review and valuable recommendations by the anonymous reviewers are appreciatively acknowledged.

\section{REFERENCES}

1. Lee, Y.H.; Shek, P.N.; Mohammad, S. (2017) Structural performance of reinforced inte rlocking blocks column. Constr. Build. Mater. 142, 469-481. https://doi. org/10.1016/j.conbuildmat.2017.03.110

2. Bosiljkov, V.Z.; Totoev, Y.Z.; Nichols, J.M. (2005) Shear modulus and stiffness of brickwork masonry: An experimental perspective. Struct. Eng. and Mech. 20 [1], 21-43. https://doi.org/10.12989/sem.2005.20.1.021

3. Jaafar, M.S.; Thanoon, W.A.; Najm, A.M.S.; Abdulkadir, M.R.; Ali, A.A.A. (2006) Strength correlation between individual block, prism and basic wall panel for load bearing interlocking mortarless hollow block masonry. Constr. Build. Mater. 20 [7], 492-498. https://doi.org//10.1016/j. conbuildmat.2005.01.046

4. Juarez, C.; Guevara B.; Valdez, P.; Durán-Herrera, A. (2010) Mechanical properties of natural fibers reinforced sustainable masonry. Constr. Build. Mater. 24, 1536-1541. https://doi.org//10.1016/j.conbuildmat.2010.02.007

5. Martínez, M.; Atamturktur, S. (2019) Experimental and numerical evaluation of reinforced dry-stacked concrete masonry walls. J. Build. Eng.22, 181-191. https://doi. org/10.1016/j.jobe.2018.12.007

6. Anand, K.B.; Ramamurthy, K. (2000) Development and performance evaluation of interlocking-block masonry. J. Architect. Eng. 6 [2], 45-50. https://doi.org/10.1061/ (ASCE)1076-0431(2000)6:2(45)

7. Kintingu, S.H. (2009). Design of interlocking bricks for enhanced wall construction, flexibility, alignment accuracy and load bearing. Doctoral Thesis, Univerisy of Warwick, UK.

8. Fundi, S.I.; Kaluli, J.W.; Kinuthia, J. (2018) Performance of interlocking laterite soil block walls under static loading. Constr. Build. Mater. 171, 75-82. https://doi.org/10.1016/j. conbuildmat.2018.03.115

9. Dehghan, S.M.; Najafgholipour, M.A.; Baneshi, V.; Rowshanzamir, M. (2018) Mechanical and bond properties of solid clay brick masonry with different sand grading. Constr. Build. Mater. 174, 1-10. https://doi.org/10.1016/j. conbuildmat.2018.04.042

10. Chewe Ngapeya, G.G. Waldmann, D; Scholzen, F. (2018) Impact of the height imperfections of masonry blocks on the load bearing capacity of dry-stack masonry walls. Constr. Build. Mater. 165, 898-913. https://doi. org/10.1016/j.conbuildmat.2017.12.183

11. Gupta, R. (2014) Characterizing material properties of cement-stabilized rammed earth to construct sustainable insulated walls. Case Stud. Constr. Mater. 1, 60-68. https:// doi.org/10.1016/j.cscm.2014.04.002

12. Tripura, D.D.; Singh, K.D. (2018) Mechanical behaviour of rammed earth column: A comparison between unreinforced, steel and bamboo reinforced columns. Mater. Construcc. 68 [332]. https://doi.org/10.3989/mc.2018.11517

13. Pereira, M.; Fujiyama, R.; Darwish, F.; Alves, G. (2015) On the Strengthening of Cement Mortar by Natural Fibers. Am. J. Mater. 18 [1], 177-183. https://doi. org/10.1590/1516-1439.305314

14. Savastano, H.; Warden, P.G.; Coutts, R.S.P. (2003) Potential of alternative fibre cements as building materials for developing areas. Cem. Concr. Comp. 25 [6], 585-592. https://doi.org/10.1016/s0958-9465(02)00071-9

15. Savastano, H.; Santos, S.F.; Radonjic, M.; Soboyejo, W.O. (2009) Fracture and fatigue of natural fiber-reinforced cementitious composites. Cem. Concr. Comp. 31 [4], 232-243. https://doi.org/10.1016/j.cemconcomp.2009.02.006

16. Zych, T.; Wojciech, K. (2012) Study on the properties of cement mortars with basalt fibres. Brittle Matrix Composites. Woodhead Publishing: 155-166. https://doi. org/10.1533/9780857099891.155

17. Asadi, A.; Baaij, F.; Mainka, H.; Rademacher, M.; Thompson, J.; Kalaitzidou, K. (2017) Basalt fibers as a sustainable and cost-effective alternative to glass fibers in sheet molding compound (SMC). Comp. Part B: Eng., 123, 210-218. https://doi.org/10.1016/j.compositesb.2017. 05.017

18. Ali, M.; Liu, A ; Sou, H ; Chouw, N (2012) Mechanical and dynamic properties of coconut fibre reinforced concrete. Constr. Build. Mater. 30, 814-825. https://doi. org/10.1016/j.conbuildmat.2011.12.068

19. Lertwattanaruk, P.; Suntijitto, A. (2015) Properties of natural fiber cement materials containing coconut coir and oil palm fibers for residential building applications. Constr. Build. Mater.94, 664-669. https://doi.org/10.1016/j. conbuildmat.2015.07.154

20. Toihidul Islam, M.; Bindiganavile, V. (2011) The impact resistance of masonry units bound with fibre reinforced mortars. Constr. Build. Mater. 25 [6], 2851-2859. https:// doi.org/10.1016/j.conbuildmat.2010.12.049

21. EN 1015-11:2000Methods of test for mortar for masonry. Part 11: Determination of flexural and compressive strength of hardened mortar.

22. Khedari, J.; Watsanasathaporn, P.; Hirunlabh, J. (2005) Development of fibre-based soil-cement block with low thermal conductivity. Cem. Concr. Comp. 27 [1], 111-116. https://doi.org/10.1016/j.cemconcomp.2004.02.042

23. Khedari, J.; Suttisonk, B.; Pratinthong, N.; Hirunlabh, J. (2001) New lightweight composite construction materials with low thermal conductivity. Cem. Concr. Comp. 23 [1], 65-70. https://doi.org/10.1016/S0958-9465(00)00072-X

24. Asasutjarit, C.; Charoenvai, S.; Hirunlabh, J; Khedari, J. (2009) Materials and mechanical properties of pretreated coir-based green composites. Comp. Part B: Eng. 40 [7], 633-637. https://doi.org/10.1016/j.compositesb.2009.04.009

25. Ramamoorthy, S.K.; Skrifvars, M.; Persson, A. (2015) A Review of Natural Fibers Used in Biocomposites: Plant, Animal and Regenerated Cellulose Fibers. Polymer Reviews, 55 [1], 107-162. https://doi.org/10.1080/15583724 2014.971124

26. Zhang, K.; Wang, F.X.; Liang, W.Y.; Wang, Z.Q.; Duan, Z.W.; Yang, B. (2018) Thermal and Mechanical Properties of Bamboo Fiber Reinforced Epoxy Composites. Polymers, 10 [6], 18. https://doi.org/10.3390/polym10060608

27. Naveen, J.; Jawaid, M.; Amuthakkannan, P.; Chandrasekar, M. (2019) Mechanical and physical properties of sisal and hybrid sisal fiber-reinforced polymer composites. Mechanical and Physical Testing of Biocomposites, Fibre-Reinforced Composites and Hybrid Composites. Woodhead Publishing, 427-440. https://doi.org/10.1016/ B978-0-08-102292-4.00021-7 
28. Khonsari, S.V.; Eslami, E.; Anvari, A. (2018) Fibrous and non-fibrous Perlite concretes-experimental and SEM studies. European J. Environm. Civil Eng., 22 [2], 138-164. https://doi.org/10.1080/19648189.2016.1182083

29. EN 1052-1:1999. Methods of test for masonry. Determination of compressive strength.

30. Zia, A.; Ali, M. (2017) Behavior of fiber reinforced concrete for controlling the rate of cracking in canal-lining. Constr. Build. Mater. 155, 726-739. https://doi.org/10.1016/j. conbuildmat.2017.08.078

31. Guerreiro, J.; Proença, J.; Ferreira, J.G.; Gago, A. (2018) Experimental characterization of in-plane behaviour of old masonry walls strengthened through the addition of CFRP reinforced render. Comp. Part B: Eng.148, 14-26. https://doi.org/10.1016/j.compositesb.2018.04.045

32. Marcari, G.; Manfredi, G.; Prota, A.; Pecce, M. (2007) In-plane shear performance of masonry panels strengthened with FRP. Comp. Part B: Eng. 38 [7-8], 887-901. https:// doi.org/10.1016/j.compositesb.2006.11.004

33. Dizhur, D.; Griffith, M.; Ingham, J. (2014) Out-of-plane strengthening of unreinforced masonry walls using near surface mounted fibre reinforced polymer strips. Eng. Struct. 59, 330-343. https://doi.org/10.1016/j.engstruct. 2013.10.026 